\title{
Evolution of volcanism and faulting in a segment of the Mid-Atlantic Ridge at $25^{\circ} \mathrm{N}$
}

\author{
Johnson R. Cann \\ School of Earth Sciences, University of Leeds, Woodhouse Lane, L52 9JT Leeds, UK (joe@earth.leeds.ac.uk) \\ Deborah K. Smith \\ Department of Geology and Geophysics, Woods Hole Oceanographic Institution, MS 22, Woods Hole, Massachusetts \\ 02543, USA
}

[1] We reconstruct the volcanic and tectonic evolution over the last 250,000 years of the median valley floor in the spreading segment of the Mid-Atlantic Ridge centered at $25^{\circ} \mathrm{N}$. In the center of the segment, multibeam bathymetry and deep-towed side-scan images show a large area of smooth-textured lava flows more like those of the East Pacific Rise than those of the Mid-Atlantic Ridge. Hummocky flows more typical of the MidAtlantic Ridge are found toward the southern end of the segment. The presence of the abundant smoothtextured flows allows us to interpret the volcanic and tectonic relationships in the segment. We construct a geological map using (1) multibeam bathymetry to identify the key volcanic structures and fault scarps and (2) high-resolution TOBI side-scan sonar images to interpret age relationships between features on the basis of overall sediment cover as shown by backscatter brightness. Bottom photographs across key features on the median valley floor yield detailed information on stratigraphic relationships between volcanic features and faults and allow us to calibrate backscatter brightness in terms of sediment cover and hence of age. In this way we derive a history of volcanic activity and deformation in a detailed survey area at the segment center, with the most recent flows erupted about 5000 years ago, and the youngest smooth flows about 10,000 years ago, separated by an episode of faulting. Using bathymetry and side-scan surveys, we extrapolate this to the whole of the median valley floor. The volcanic activity giving rise to the smooth flows has been continuous for about a quarter of a million years at the segment center. Over the same period, hummocky flows have been continuously erupted at the southern end of the segment. Electron probe analyses of dredged basalt glasses show that there is a systematic variation in composition with position in the segment. Basalts from the segment center are all more evolved than those at the southern end of the segment. There is, however, no relation of chemistry with lava type. The basalts from the segment center have very nearly the same composition whether they come from hummocky flows or smooth flows. The boundary between the smooth flows and hummocky flows has fluctuated with time and migrated rapidly northward over the last few thousand years, so that shortly the eruption of smooth flows will probably have ceased. The survey shows that flows that are smooth on sidescan images are not necessarily sheet flows. In this study they uniformly show pillow morphology. We conclude that smooth flows were probably erupted at faster eruption rates than hummocky flows.

Components: 12,997 words, 7 figures, 2 tables.

Keywords: Mid-Atlantic Ridge; volcanism; faulting; tectonic history; smooth-textured flows; hummocky flows.

Index Terms: 3035 Marine Geology and Geophysics: Midocean ridge processes; 8416 Volcanology: Mid-oceanic ridge processes (1032, 3614); 8425 Volcanology: Effusive volcanism; 8429 Volcanology: Lava rheology and morphology; 3075 Marine Geology and Geophysics: Submarine tectonics and volcanism.

Received 24 February 2005; Revised 27 April 2005; Accepted 28 June 2005; Published 9 September 2005.

Cann, J. R., and D. K. Smith (2005), Evolution of volcanism and faulting in a segment of the Mid-Atlantic Ridge at $25^{\circ} \mathrm{N}$, Geochem. Geophys. Geosyst., 6, Q09008, doi:10.1029/2005GC000954. 


\section{Introduction}

[2] The Mid-Atlantic Ridge (MAR) is divided into many spreading segments, each tens of kilometers long, and each with a distinct style of volcanism compared with its neighbors [e.g., Sempéré et al., 1993; Smith et al., 1995; Thibaud et al., 1998]. One especially distinctive segment is that centered on $25^{\circ} \mathrm{N}$. On bathymetric maps derived from multibeam echo sounder data its median valley floor is broad, about 11 kilometers wide, and remarkably flat, especially in the center of the segment (Figure 1a). It is the only one of the eighteen spreading segments identified between the Kane and Atlantis transforms $\left(24-30^{\circ} \mathrm{N}\right)$ at the MAR not to possess an axial volcanic ridge within the median valley floor [Smith et al., 1995]. In the other segments axial volcanic ridges are constructed by submarine eruptions and may reach heights of several hundreds of meters, widths of several kilometers and lengths of several tens of kilometers [Ballard et al., 1979; Smith and Cann, $1992,1993]$. By contrast, the segment at $25^{\circ} \mathrm{N}$ has a shallow (1-2 km wide, by $150-250 \mathrm{~m}$ deep) central depression within the median valley floor, extending along much of the length of the segment (Figures $1 \mathrm{a}$ and $1 \mathrm{~b}$ ). Isolated volcanic edifices of various shapes and sizes rise from the almost flat plain of the median valley floor in the segment center. Toward the southern end of the segment the seafloor becomes rougher because volcanic constructions of a wide range of sizes, including a few large seamounts, predominate. At the northern end of the segment, close to $25^{\circ} 20^{\prime} \mathrm{N}$, there is a small $(1-2 \mathrm{~km})$ offset between this segment and one containing a major axial volcanic ridge. At the south end, close to $24^{\circ} 55^{\prime} \mathrm{N}$, a large offset separates the segment from one of a number of short segments that in total lead to a $50 \mathrm{~km}$ dextral displacement of the spreading axis [Smith et al., 1995; Spencer et al., 1997]. The offsets at both ends of the segment are termed non-transform offsets since they do not involve a single identifiable transform fault.

[3] Our side-scan survey of the $25^{\circ} \mathrm{N}$ segment using the near bottom ( $\sim 500 \mathrm{~m}$ asf) side-scan instrument TOBI [Smith et al., 1995] suggested that the topography in the center of the segment is the result of eruption of low-relief lava flows that mantle the valley floor. These flows have a smooth texture on the high-resolution $(\sim 5 \mathrm{~m}$ pixel size) side-scan sonar imagery. This is very unusual for segments of the Mid-Atlantic Ridge, since in almost all other segments for which we have side- scan coverage [e.g., Briais et al., 2000; Lawson et al., 1996; Smith et al., 1995] the volcanics are hummocky-textured, composed of the overlapping volcanic mounds that we have termed hummocks. The mosaic from the side-scan survey of this segment is shown draped on a perspective view of $3 \mathrm{D}$ multibeam bathymetry in Figure $1 \mathrm{~b}$. We suggested [Smith et al., 1995] that these smooth flows might have been erupted during a recent major volcanic event that had buried the pre-existing topography. Other evidence suggesting a relatively hot thermal regime beneath the axis, and hence the possibility of a recent voluminous magmatic event, includes (1) an along axis variation in the mantle Bouguer gravity anomaly $(\sim 14 \mathrm{mGal})$ with the minimum located just north of the segment center [Thibaud et al., 1998] indicating a corresponding variation in crustal thickness with thicker crust close to the segment center [Tucholke et al., 1997], (2) a corresponding along-axis change in axial depth of $\sim 400 \mathrm{~m}$ from the southern end to the shallower segment center, and (3) the relatively shallow water depth at the segment center $(3500 \mathrm{~m})$ [Smith et al., 2002b]. The relatively small gradient in the mantle Bouguer gravity anomaly and a relatively small change in relief along the axis compared with other segments in the area, combined with the shallow depth at the segment center, suggests to us that this is a magmatically active segment, but that the magmatism is spread out along the axis rather than strongly focused at the segment center.

[4] The particular volcanic characteristics of this segment allow us to consider a number of questions that are hard to approach elsewhere on the Mid-Atlantic Ridge. Using a set of photographs from a recently run camera tow across critical features in the center of the $25^{\circ} \mathrm{N}$ segment, we test what we can infer about eruption characteristics from the texture of the side-scan images: is the side-scan texture of a flow unit (smooth and hummocky) related to the small-scale lava morphology (pillows, lobates and sheets)? We examine the relationship between the smooth-textured flows, characteristic of much of the seafloor at the axis of the East Pacific Rise [e.g., Crane, 1987; White et al., 2002] and the hummocky flows more typical of the Mid-Atlantic Ridge. We consider both the co-existence of the two textures of flow within a single segment, and the relationship between the two side-scan textures in the segment both in space and time. Finally, we use the bathymetry, side-scan imagery and photographs to reconstruct the volcanic and structural history of 
a)

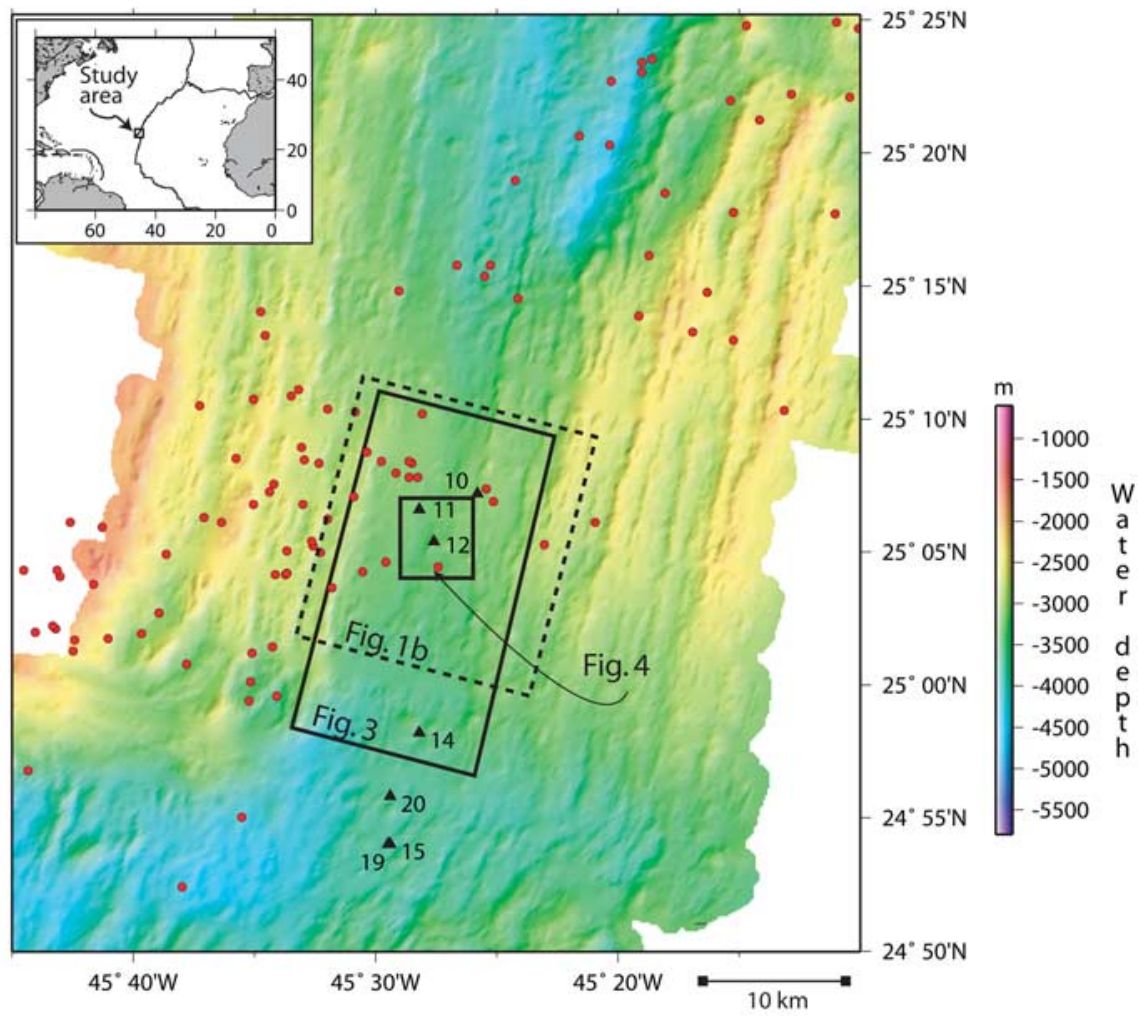

b)

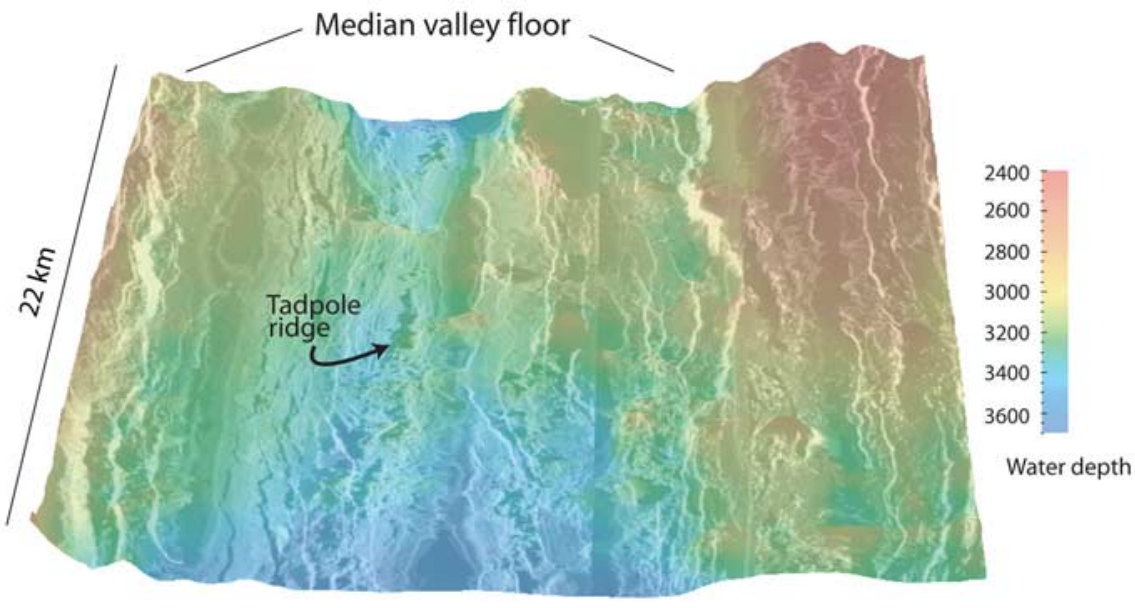

$15 \mathrm{~km}$

Figure 1. (a) Multibeam bathymetry of the $25^{\circ} \mathrm{N}$ segment [Purdy et al., 1990]. In the center of the segment the valley floor is abnormally smooth compared to other segments of the northern Mid-Atlantic Ridge, while toward the south end of the segment volcanic ridges and seamounts are much more typical of slow-spreading ridges are observed. The small gradient in mantle Bouguer anomaly, the small change in relief along axis, and the shallow depth of the axis suggest that this is a magmatically active segment, with magmatism spread out along the axis. Red dots: calculated locations of seismic events detected by an Atlantic hydrophone array [Smith et al., 2003]. The seismicity clusters on the inside corner high, typical of other segments of the northern Mid-Atlantic Ridge. Black triangles: sites of dredges. (b) TOBI side-scan mosaic used as shading for a 3-D bathymetric surface of a section of the $25^{\circ} \mathrm{N}$ segment. Light is strong acoustic backscatter; dark is weak backscatter or acoustic shadow. Color: water depth as shown in the color bar. The extent of the area shown in this image is outlined in Figure 1a. Tadpole ridge is marked. 
Table 1. Summary of Electron Probe Analyses of Glasses From $25^{\circ} \mathrm{N}$ at the $\mathrm{MAR}^{\mathrm{a}}$

\begin{tabular}{|c|c|c|c|c|c|c|c|}
\hline $\begin{array}{l}\text { Dredge } \\
\text { Latitude, N } \\
\text { Longitude, W }\end{array}$ & $\begin{array}{c}10 \\
25.12 \\
45.43\end{array}$ & $\begin{array}{c}11 \\
25.11 \\
45.47\end{array}$ & $\begin{array}{c}12 \\
25.09 \\
45.46\end{array}$ & $\begin{array}{c}14 \\
24.97 \\
45.47\end{array}$ & $\begin{array}{c}15 \\
24.90 \\
45.49\end{array}$ & $\begin{array}{c}19 \\
24.90 \\
45.49\end{array}$ & $\begin{array}{c}20 \\
24.93 \\
45.49\end{array}$ \\
\hline $\mathrm{SiO}_{2}, \mathrm{wt} \%$ & 50.2 & & & 50. & 50.06 & 50.27 & 50.33 \\
\hline $\mathrm{TiO}_{2}$ & .50 & 1.37 & 1.51 & 1.21 & 1.09 & 1.12 & 1.34 \\
\hline A & 14.49 & 14.49 & 14.53 & 14.99 & 15.18 & 15.88 & 15.60 \\
\hline & 9.29 & 8.83 & 9.28 & 8.8 & & 8.09 & 8.71 \\
\hline & 0 & 0.1 & 0.19 & & 0.1 & 0 . & 0.08 \\
\hline & 7.49 & 7.68 & 7.44 & 8.1 & 8.50 & 8.50 & 8.15 \\
\hline & 10.98 & 11.44 & 11.19 & 11.99 & 12.06 & 12.12 & 11.95 \\
\hline & & & & & & 2. & 2.72 \\
\hline & & 0.09 & 0.14 & & & 0.05 & 0.08 \\
\hline $\mathrm{P}_{2} \mathrm{O}_{5}$ & 0.19 & 0.15 & 0.19 & 0.15 & 0.16 & 0.09 & 0.11 \\
\hline & 97.63 & 97.69 & 98.21 & 98.65 & 98.31 & 98.99 & 99.28 \\
\hline Mg\# & 58.5 & 60.3 & 58.3 & 61.8 & 63.8 & 64.9 & 62.3 \\
\hline
\end{tabular}

${ }^{\mathrm{a}}$ Each analysis is a mean of 5 determinations on one glass fragment from one rock sample in a given dredge haul. Other glass fragments in the same dredge haul were analyzed and gave results indistinguishable from that quoted.

the segment, over the last 30,000 years, and by extrapolation over the last 250,000 years.

\section{Data Collection}

[5] The first multibeam bathymetric survey of this segment and the others between $24^{\circ}-30^{\circ} \mathrm{N}$ was reported by Purdy et al. [1990] and Sempéré et al. [1993]. The track spacing of the survey left significant gaps at the depths of the median valley floor. In 2001, we made a complete bathymetric survey of the $25^{\circ} \mathrm{N}$ segment on $\mathrm{R} / \mathrm{V}$ Knorr, cruise 161 using the SeaBeam 2100 system. Two tracks were run parallel to the segment and cover the inner valley floor out to the crestal mountains.

[6] Previously on RRS Charles Darwin cruise 65, we collected high-resolution side-scan imagery with the Southampton Oceanography Centre's Towed Ocean Bottom Instrument (TOBI) [Smith et al., 1995]. TOBI operates at $30 \mathrm{kHz}$, is towed 200-500 $\mathrm{m}$ above the seafloor at $1-2 \mathrm{kt}$, and covers a total swath width of $6 \mathrm{~km}$. Across the track, the spatial resolution of the image varies with distance from the nadir, but is typically a few meters. Along the track the resolution is somewhat lower than across track. The survey was planned with a three-kilometer line spacing to give almost total dual insonification of the median valley floor, ensuring that no feature could be hidden in shadow, and that all faults would from one direction or the other, show backscatter from the fault scarp.

[7] On the same cruise of RRS Charles Darwin we made seven successful dredge hauls of basalt from the floor of the median valley of the $25^{\circ} \mathrm{N}$ segment. Locations of the hauls are given in Table 1 and shown in Figure 1. Glasses from these hauls were analyzed using the Cameca electron probe of the University of Leeds.

[8] In addition to the new multibeam data, we obtained seafloor photographs in 2001 using the Woods Hole Oceanographic Institution's Towcam system [Fornari, 2003]. The camera track was run across the median valley floor at $\sim 25^{\circ} 5.2^{\prime} \mathrm{N}$ imaging two distinctive volcanic edifices (a faulted volcanic cone and a small linear volcanic ridge) as well as the smooth-textured plains surrounding them. The camera was towed 8-10 meters above the ocean floor, at $0.25-0.5 \mathrm{kt}$, taking a picture every $13 \mathrm{~s}$. The width of the field of view depends on the height of the camera above the bottom which varied from about 5 to $10 \mathrm{~m}$, giving widths of the field of view of $6-8 \mathrm{~m}$.

\section{Results}

\subsection{Multibeam Bathymetry}

[9] The map of multibeam bathymetry in Figure 1a shows the full length of the $25^{\circ} \mathrm{N}$ segment. The median valley floor can be divided into three sections from north to south. There is a gradational transition between them, but each is distinct. In the northern section, north of $25^{\circ} 10^{\prime} \mathrm{N}$, the volcanic axis lies in a valley within the median valley floor bounded on the east by a large scarp about $150 \mathrm{~m}$ high. The scarp runs for $20 \mathrm{~km}$ from the north end of the segment south into the central section and terminates at $25^{\circ} 08^{\prime} \mathrm{N}$ (Figure 2). The topography within this part of the $25^{\circ} \mathrm{N}$ segment shows abundant small volcanic cones.

[10] In the southern section of the $25^{\circ} \mathrm{N}$ segment, south of $24^{\circ} 58^{\prime} \mathrm{N}$, the volcanic axis of the segment is bordered to the west by a major deep that represents the start of the large non-transform offset at this latitude. The volcanic axis itself, as at the northern end of the segment, is marked by abundant small volcanic cones with one or two reaching heights of 100-200 m.

[11] The $20 \mathrm{~km}$ long central section of the segment between $24^{\circ} 58^{\prime} \mathrm{N}$ and $25^{\circ} 10^{\prime} \mathrm{N}$ is very different from the ends (Figure 2). Throughout the central 


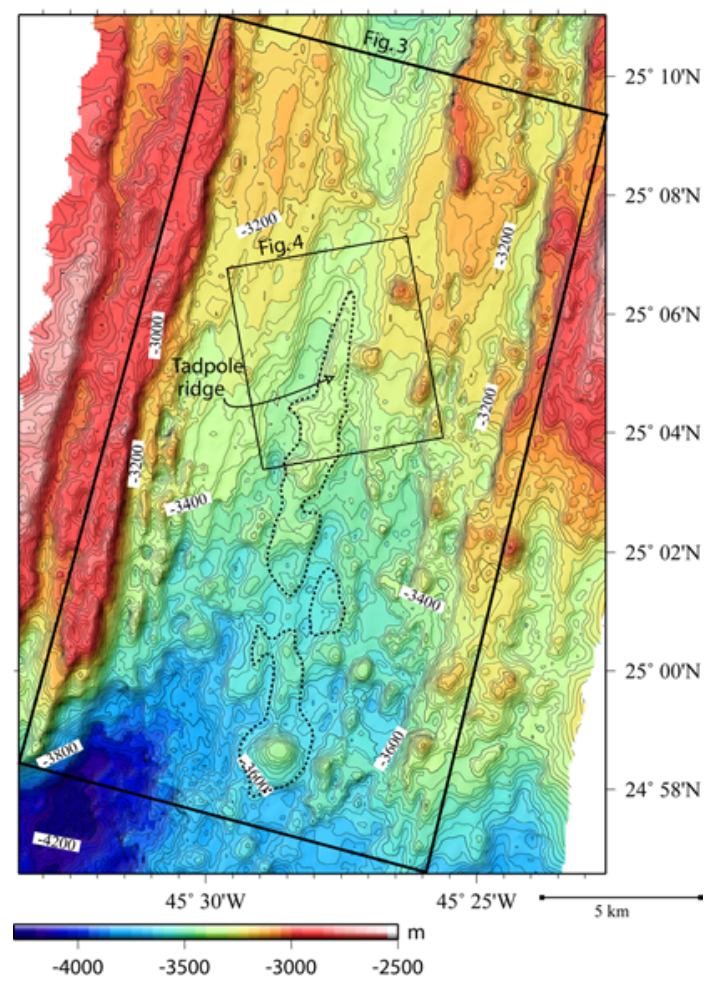

Figure 2. Multibeam bathymetry of the $25^{\circ} \mathrm{N}$ segment collected in 2001 on RV Knorr cruise 161. Location of the region is shown in Figure 1a. Colors: water depths as shown by the color bar. Contour interval is $25 \mathrm{~m}$. Black triangles: sites of dredges. Dashed line: location of the most recent flows within the median valley floor. Black rectangles: areas shown in Figures 3 and 4.

section the median valley floor slopes gently from its edges down toward its center, and there is remarkably little topographic expression of the volcanism. One or two cones are scattered over the gently sloping plain that occupies most of the median valley floor. There is an axial depression that is $1-2 \mathrm{~km}$ wide and 150-200 $\mathrm{m}$ deep in the central part of this segment. This is in contrast to other segments at the northern Mid-Atlantic Ridge, where an axial volcanic ridge is commonly observed in the central parts [Smith et al., 1995].

\subsection{Side-Scan Sonar}

[12] A mosaic of the TOBI side-scan sonar images of the central section is shown in Figure 3a. The extent of the mosaic is indicated in Figures 1a and 2. Side-scan data covering a larger section of the segment are shown draped on bathymetry in Figure $1 \mathrm{~b}$ (Tadpole ridge can be used as a reference point in Figures $1 \mathrm{~b}$ and $3 \mathrm{a}$ ). The mosaic in Figure $3 \mathrm{a}$ includes the central section of the segment and also the transition into both the northern and southern sections. The direction of insonification varies across the image, which is composed of parts of three 6-km-wide swaths. Using the results of the side-scan survey together with the multibeam bathymetry, we constructed a geological interpretation of the survey area (Figure $3 \mathrm{~b}$ ). This distinguishes a number of geological features as described below.

[13] The side-scan mosaic shows that the central section of the median valley floor is bordered by major fault zones, throwing down toward the spreading axis. Faults are identified as broadly linear, brightly backscattering features (bright when insonified toward the scarp face, but throwing shadows when insonified in the opposite direction). On some of the scarps it is possible to distinguish rocky crags above a smooth talus ramp [Blackman et al., 1998; McAllister et al., 1995; McAllister and Cann, 1996]. An indication of fault throw comes from the width of the backscatter from the scarp on the side-scan image; we show the width of the zone of bright backscatter on the geological map (Figure 3b).

[14] The fault on the west side of the valley floor has a much greater throw than that on the east, perhaps reflecting its position on the inside corner of the major non-transform offset at the south end of the segment (Figures 1 and 2). Zones of numerous smaller faults cut the floor of the median valley. These minor faults almost all throw down toward the topographic low that runs up the center of the median valley floor. A large part of the deepening of the seafloor toward the topographic low is likely related to the displacement on the many small faults.

[15] We distinguish two flow textures from the sidescan imagery: smooth and hummocky. Smooth flows are distinguished from hummocky flows by their uniform texture and lack of the shadows cast by individual hummocks and the edifices built of hummocks. As seen in Figure 3 a much of the median valley floor in the central section of the segment is covered with smooth-textured flows. Figure $3 \mathrm{a}$ also shows that the amplitude of sonar backscatter from the smooth flows decreases toward the edges of the median valley floor. The flows close to the center on the median valley floor are bright, while those close to the edge are very dark, suggesting that flows far from the center of the floor are more thickly sediment-covered [Mitchell, 1993], and hence older than the flows close to the central topographic low. An age difference between flows at 
the center and edge of the median valley floor implies that volcanism of the type that produces side-scan-smooth flows has been continuing for a significant length of time in the segment.

[16] In the southern section of the segment (Figure 3a) most of the volcanics have a hummocky texture. Hummocky-textured flows are composed of overlapping volcanic mounds (hummocks), 50 to $200 \mathrm{~m}$ in diameter and up to a few tens of meters high interspersed with larger constructions up to $200 \mathrm{~m}$ tall. Hummocky-textured flows are very characteristic of northern Mid-Atlantic Ridge volcanism [e.g., Briais et al., 2000; Lawson et al., 1996; Smith and Cann, 1993; Smith et al., 1995]. Some of the taller features are piles of hummocks, while others are flat-topped structures with steep sides. The most prominent boundary between the smooth and hummocky volcanics forms the shape of an arrowhead pointing north in the center of the median valley floor in the central section of the segment, indicating that the boundary has been migrating north recently (Figure $3 \mathrm{a}$ ). The apex of this arrowhead is a hummocky ridge close to $25^{\circ} 05^{\prime} \mathrm{N}$, which has been informally named "Tadpole ridge" because of its shape. The amplitude of backscatter from the hummocky flows in the southern section of the segment, south of Tadpole ridge,

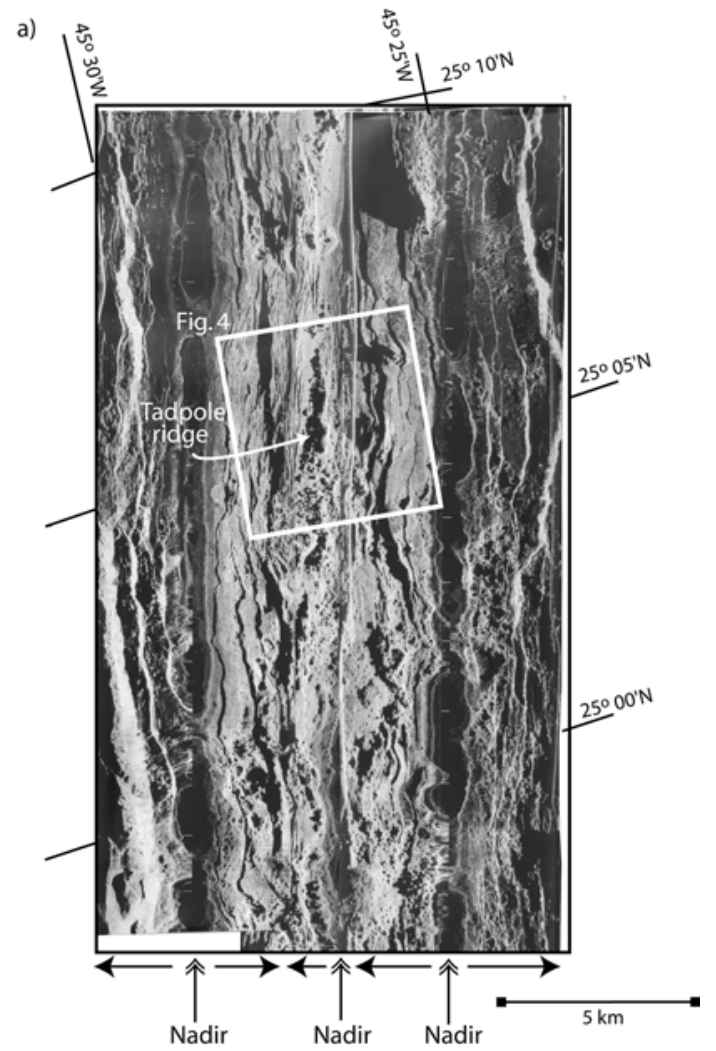

decreases toward the edge of the median valley floor, just as happens with the smooth-textured flows, though this is not so easy to see as on the smooth flows. The decreasing backscatter suggests increased sediment cover and increasing age with distance from the median valley axis.

[17] Isolated volcanic constructions form peaks or ridges throughout the area of Figure 3a, both in areas of smooth and hummocky volcanics. Some of these are capped by smooth-textured, flat surfaces, surrounded by steep slopes, while others are more conical in cross section and appear to be constructed of piles of hummocks. Such constructions range in height from less than $20 \mathrm{~m}$ to over $200 \mathrm{~m}$, and have a radius usually about ten times their height.

[18] In Figure 3b smooth and hummocky-textured flows are divided into three relative age groups

Figure 3. (a) TOBI side-scan mosaic of the center of the median valley floor. The mosaic is made of parts of three swaths, each $6 \mathrm{~km}$ wide, run parallel to the axis of the median valley. The location of the mosaic within the $25^{\circ} \mathrm{N}$ segment is shown in Figure 1a. Light is strong acoustic backscatter; dark is weak backscatter or acoustic shadow. The uniformly gray areas in the upper part of the mosaic are smooth-textured flows, more sedimented toward the margins of the valley floor, and cut by zones of small faults. Toward the southern end of the segment the flows are hummocky textured. Note the decrease in intensity of backscatter from the smooth flows with distance from the center of the median valley, indicating that that sediment cover increases toward the edge of the valley floor. Smooth flows show a wide range of intensity of backscatter, implying a corresponding variation in sediment cover, in turn indicating a prolonged period during which smooth flows were erupted. Tadpole ridge is marked. White box: area in Figure 4. (b) Geological interpretation of the side-scan mosaic shown in Figure 3a. Isolated volcanic constructions are shown, with a blank area at the center representing a flat top, if one exists, and radiating lines marking the lateral slopes. The width of the backscatter zone from fault scarps is also indicated. From the sidescan we can identify three stages of sediment cover, representing three different ages of most recent resurfacing. $\mathrm{H} 1$ and $\mathrm{S} 1$ : youngest hummocky and smoothtextured flows identified from the side scan. H2 and S2: an earlier stage of hummocky and smooth flows. H3 and S3: the earliest hummocky and smooth-textured flows identified in the side-scan imagery. F1-F4: locations of the fault zones identified in the median valley floor. F1 is the latest and F4 faults are the earliest defining the edges of the median valley floor. Dashed line: location of the most recent flows that cover F1 faults. Black box: area in Figure 4. 
b)

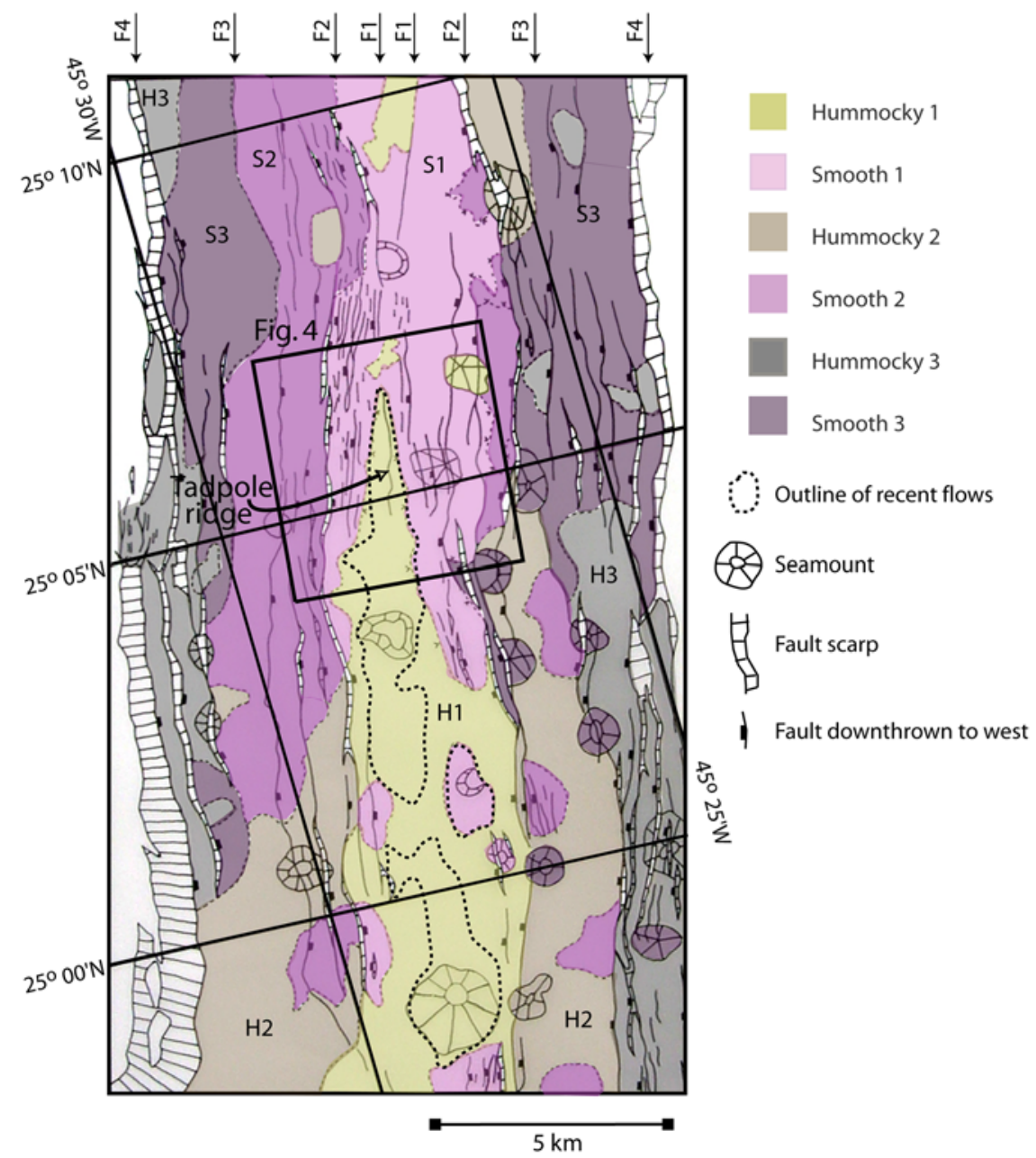

Figure 3. (continued)

(S1, S2 and S3; H1, $\mathrm{H} 2$ and $\mathrm{H} 3$ respectively) on the basis of the brightness of the backscatter from the flow surfaces, which is reduced by significant sediment cover. The $\mathrm{S} 1$ and $\mathrm{H} 1$ flows are those with the brightest backscatter and hence the thinnest sediment cover. The boundaries between the flow units of different ages are commonly abrupt rather than gradational. Isolated volcanic constructions are shown, with a blank area at the center of the image representing a flat top, if one exists, and radiating lines marking the lateral slopes. These isolated constructions are colored according to whether they are composed of smooth or hummocky-textured flows.

[19] The abrupt boundaries between the flow units of different age are commonly fault zones running parallel to the spreading axis. These fault zones form pairs approximately equidistant from the spreading axis on either side. The oldest (S3 and H3) flows are bounded on the outside by the pair of median valley wall fault zones (F4 in Figure 3b), and on the inside by a pair of discontinuous, apparently younger, fault zones (F3). The youngest (S1 and H1) flows are bounded by a pair of fault zones within the median valley floor, spaced about $4 \mathrm{~km}$ apart (F2). Cutting the youngest (S1 and H1) flows is a pair of younger fault zones, F1, spaced about $1 \mathrm{~km}$ apart, that have displaced the $\mathrm{S} 1$ flows and must postdate them. The $\mathrm{S} 2$ and $\mathrm{H} 2$ flows lie generally between the F2 and F3 fault zones, though the $\mathrm{H} 2$ flows overlap the F3 fault zone in the southwest of the area. The symmetry of the fault zones on each side of the spreading axis and the relationship between the fault zones and the relative age of the lava units suggest that the fault zones formed as pairs at approximately the same time on either side of the axis. 
a)

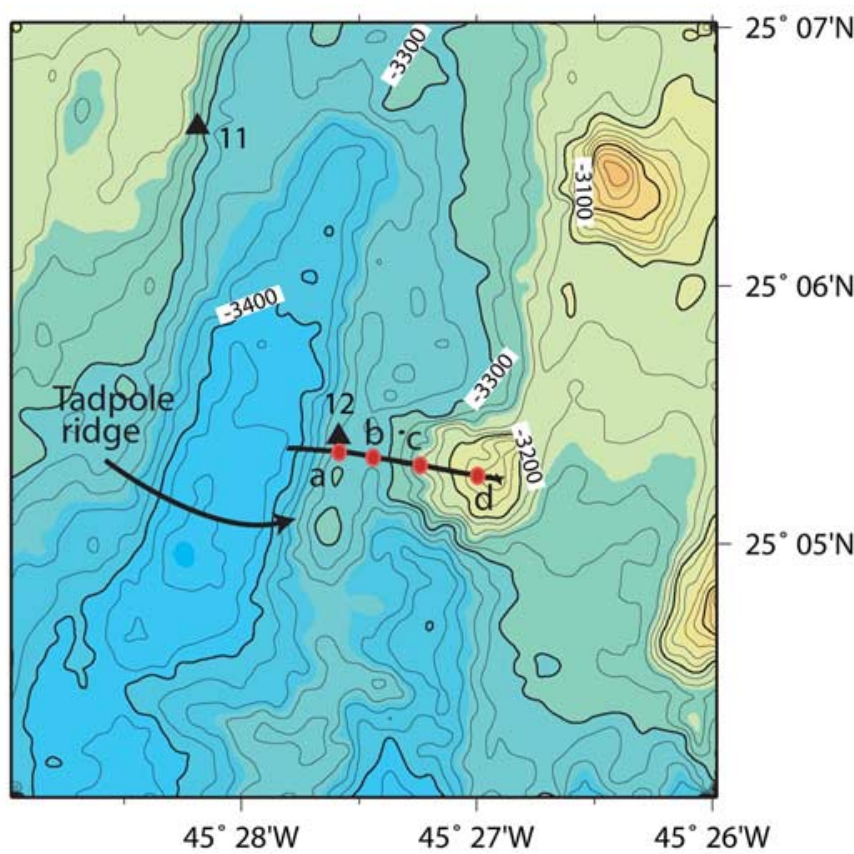

b)

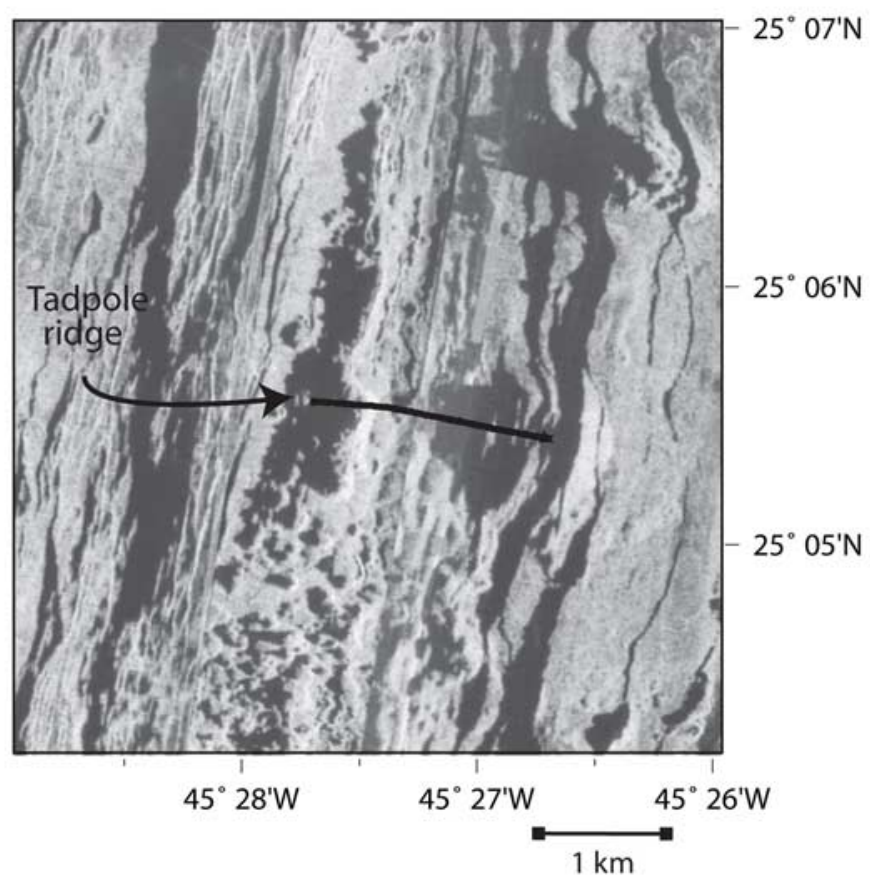

\section{6 ' $\mathrm{N}$} $\mathrm{N}$

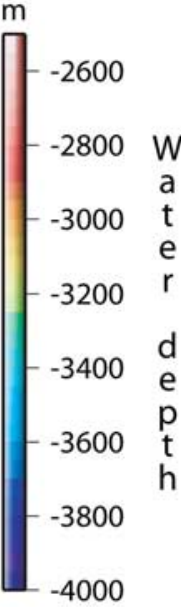

$-4000$

\section{W \\ a \\ $r$ \\ d \\ $p$ \\ $\mathrm{h}$}

Figure 4. (a) Multibeam bathymetry of the detailed study area. The location of the region is marked in Figures 1a, 2, and 3. Contour interval is $20 \mathrm{~m}$. Black line: camera track. Black triangles: sites of dredges. Red circles: locations of the photographs in Figure 5. Tadpole ridge is marked. The camera track starts on the top of a small seamount that straddles a fault, crosses an area of uplifted smooth flows, then the ridge of hummocky volcanics, and ends on the smooth lava plains of the center of the median valley floor. (b) TOBI imagery of the same area in Figure 4a, showing a ridge of hummocky volcanics, "Tadpole ridge," surrounded by smooth-textured flows, and an intensely faulted seamount east of Tadpole ridge. Between Tadpole ridge and the seamount is an uplifted area of smooth flows. The relative age of the features cannot be established from this image of relatively unsedimented flows. 
a)

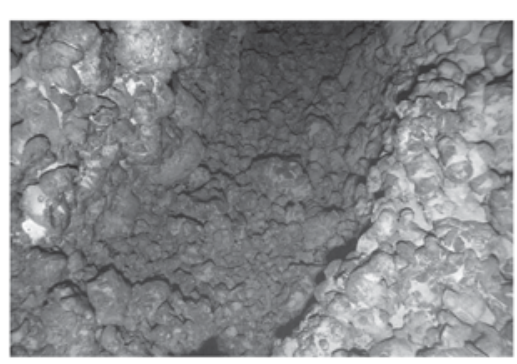

c)

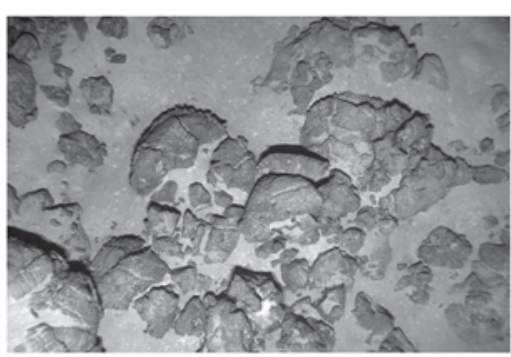

b)

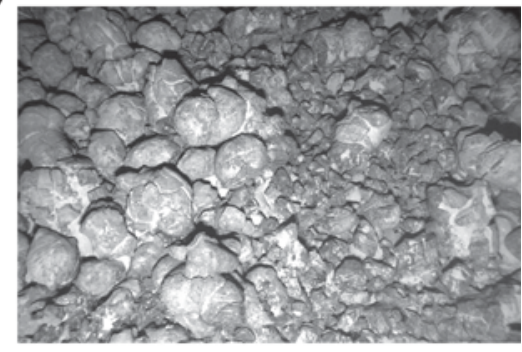

d)

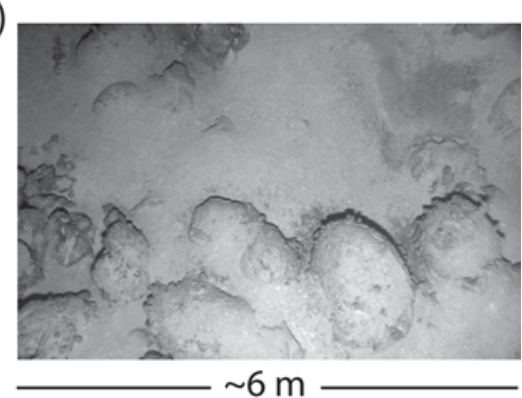

Figure 5. Four frames from the photo-transect. Locations of the photographs are shown as red circles in Figure 4. (a) Eruptive fissure from the top of Tadpole ridge. (b) Typical photograph of the youngest lava, with little sediment cover from an area east of Tadpole ridge. (c) Lava of intermediate sediment cover from the east of Tadpole ridge and typical of the smooth plains immediately west of Tadpole ridge. (d) Lava from near the top of the seamount at the east end of the photo-transect, which is the oldest feature on the transect as shown by the thickest sediment cover. Ages of the flows can be approximated from the sediment cover and from estimated sedimentation rates of about $10 \mathrm{~m} / \mathrm{Ma}$ [Lisitzin, 1972] (see text for details).

[20] Within the band of S1 and H1 lavas that covers the spreading axis are three eruptive units that can plainly be seen on the side-scan images to overlie faulted and fissured S1 or H1 flows, presumably faulted or fissured by F1 fault activity. These eruptive units all lie in the central and southern parts of the area. They are outlined in Figures 2 and $3 \mathrm{~b}$ by dashed lines.

\subsection{Camera Survey}

[21] The track of the camera tow (Figure 4) was chosen to encompass four different features identified by bathymetry and side scan: (1) the volcanic feature "Tadpole ridge" at the northern apex of the transition between hummocky and smooth-textured flows, and possibly the youngest feature in the area; (2) the smooth flows adjacent to Tadpole ridge on the west, which are the youngest smooth flows discernible on the side scan; (3) smooth flows on the east side of Tadpole ridge, at a higher elevation than those to the west, and possibly older flows elevated by faulting; and (4) an isolated volcanic construct cut by faults east of Tadpole ridge. Selected photographs from the camera tow are shown in Figure 5. An important observation from the photographs is that the upper surfaces of the lava flows imaged, whether smooth or hummocky in side-scan images, are all pillowed. We saw no lobate or sheet flow textures in our images of the lava flows.

[22] The lava flows are all covered with some sediment. Comparison of sediment thickness can be difficult where the flow morphology changes, but here we are only dealing with pillow lavas, and the task is simpler. Though the sediment thickness is locally variable, we were able to divide the sediment cover into three classes of increasing thickness. On the least sedimented flows (Figures $5 \mathrm{a}$ and $5 \mathrm{~b}$ ) the sediment cover is incomplete. A large proportion of the seafloor is sediment-free, and sediment occurs in the crevices between pillows or in cracks in the pillows. The flows with intermediate coatings of sediment (Figure 5c) still have areas of bare rock showing, but sediment fills depressions in the flow surface, as well as cracks in the pillows. In the flows with the thickest sediment cover (Figure 5d), the rock surface is largely coated with sediment, and sediment-filled depressions in the flow surfaces are more extensive. Sediment cover is thick enough in 
this type of flow for extensive bioturbation of the sediment to have been possible. Extensive bioturbation is not seen in the less-sedimented flows. Additional photographs of the variation in thickness of the sediment cover are included in the auxiliary material ${ }^{1}$ (Figures A, B, and C).

[23] On the basis of sediment thickness, Tadpole ridge must be the youngest of the four features photographed since it has the least covering of sediment on its pillowed flows (Figure 5a). About $600 \mathrm{~m}$ to the east of Tadpole ridge, small volcanic features, not individually resolved on the side scan have the same thin sediment covering as Tadpole ridge (Figure $5 \mathrm{~b}$ ) and must be about the same age. The Tadpole ridge is the northern end of one of the eruptive units identified on the side-scan imagery as being the products of the most recent volcanism in the segment (Figures 2 and $3 b$ ).

[24] The smooth-textured pillowed flows adjacent to Tadpole ridge on the west are significantly more thickly sedimented than Tadpole ridge belonging to the intermediate sediment class. Perhaps unexpectedly, the pillowed flows to the east of Tadpole ridge at a higher elevation are identical in sediment cover to the flows to the west (Figure 5c). The difference in elevation must be due to faulting that post-dates the eruption of the lavas; the fault system responsible is hidden beneath Tadpole ridge, and must predate it, but is seen on bathymetry and side scan to the north of Tadpole ridge (Figure 4).

[25] The isolated small seamount cut by faults, lying to the east of Tadpole ridge, is the oldest feature imaged by the camera (Figure 5d). There the sediment cover is the thickest imaged by the camera, thick enough to be vigorously bioturbated. It is a volcanic construction that has been sliced into a number of sections by a cluster of faults. The individual faults have throws ranging from a few meters to several tens of meters. The original shape of the edifice can be reconstructed by estimation of fault throw and dip of the lava flows from examination of the camera images. The reconstruction shows that prior to the faulting the volcanic edifice was flat-topped, with the flat top covered by pillows, and the steep sides coated by pillow flows with the pillows elongate down slope. This shape is similar to that of many of the other volcanoes imaged in this and other segments.

${ }^{1}$ Auxiliary material is available at ftp://ftp.agu.org/apend/gc/ 2005GC000954.
[26] The pillow flow units of Tadpole ridge and the other very young flows to the east of it show a number of eruptive features. Each is associated with an eruptive fissure, a few meters deep and a few meters wide, floored with pillows of smaller size than those forming the flows away from the fissures. The eruptive fissure at the crest of Tadpole ridge was clearly imaged (Figure 5a). Once or twice the camera tow crossed a fissure of similar morphology, floored by unsedimented lavas, within lavas with thicker sediment cover, of an inferred older date. We interpret these as relatively recent fissures from which no eruption took place at that locality. Where flow surfaces are close to horizontal, pillows are approximately equidimensional, but where a flow surface is inclined, as on the western flank of Tadpole ridge, pillows are elongated downslope tubes several meters long, as described above. On the western flank of Tadpole ridge, which has a slope of about $15^{\circ}$ with about 80 meters of relief, the upper part of the slope is made of elongate pillows while the lower slope is a breccia of pillow fragments (see photographs in the auxiliary material (Figure D)). There is a gradual transition between the two in the middle of the slope, with isolated elongate pillows running over breccia and pillows in process of fragmentation, suggesting that the breccia formed as part of the eruptive process. This is consistent with observations at the Puna Ridge that show similar relationships between flow morphology and underlying slope [Gregg and Smith, 2003].

[27] Talus piles were imaged both at the bottom of fault scarps, and on the western slope of Tadpole Ridge. The sediment cover on talus is not easily related to that on pillows, since the small-scale surface morphology is very different. But it was possible to divide the sediment cover on the talus into two classes. One class has very thin sediment cover, with sediment in the cracks between basalt clasts in the talus pile, and little cover on the tops of the clasts. The other class has a clearly thicker cover, with more extensive areas of complete sediment cover and a smaller proportion of the seafloor being exposed bare rock. Though the comparison must be treated with care, the talus piles with the thinner sediment cover looked very similar to the pillows with the least sediment cover, and the talus with the thicker cover seemed similar to the pillows with intermediate sediment cover. Of course the sediment cover of talus is disturbed each time the talus moves, and does not reflect the ultimate age of the talus pile. Images of the 
sediment cover on the talus are shown in the auxiliary material (Figure E).

\subsection{Dredge Hauls}

[28] Seven successful dredge hauls of basalt were made in the area (see Figures 1, 2, and 4 and Table 1 for locations). Each dredge haul was scanned for differences in appearance of the rocks, but each haul seemed to represent material of a single type. Two dredges (10 and 11) were made on smooth lava flows in the central section of the segment, recovering fragments of pillow basalts with glassy margins, which are aphyric to sparsely phyric. Dredge 12 was from Tadpole ridge and brought up a large number of fragments of sparsely phyric basaltic pillows with glassy margins. The remaining four dredges were made in the southern part of the segment. Two dredges (15 and 19) were made from the same 200-m-tall volcanic edifice, and recovered small fragments of moderately plagioclase and olivine-phyric basalt with glassy margins. Dredge 14 was on a volcanic edifice north of the dredges 15 and 19, and recovered moderately plagioclase-phyric fragments of glassy basalt. Dredge 20 was from a hummocky edifice between dredges 15 and 14, and recovered highly porphyritic fragments of pillow basalt. The abundant plagioclase phenocrysts include both sievetextured forms and more normal forms with large, uniform cores surrounded by zoned margins. Olivine phenocrysts are subordinate to the plagioclase phenocrysts.

[29] Electron probe analysis of glasses from seven of the dredge hauls show that all are N-MORBS, judging by their contents of incompatible elements, and by their $\mathrm{K} / \mathrm{Ti}$ ratios (Table 1 ). The compositions vary from more-evolved samples richer in $\mathrm{TiO}_{2}(1.5 \%)$ and with a lower $\mathrm{Mg}$ number (58\%), to less-evolved samples poorer in $\mathrm{TiO}_{2}(1.1 \%)$ and with a higher $\mathrm{Mg}$ number (64\%) (Figure 6a). The variation in major element geochemistry (examples are shown in Figures $6 \mathrm{~b}$ and $6 \mathrm{c}$ ) is consistent with the precipitation of about $30 \%$ of a plagioclase-rich gabbroic cumulate from the most Ti-poor liquids to generate the most Ti-rich liquids (approximately $55 \%$ plagioclase, $30 \%$ clinopyroxene and 15\% olivine). Though there are few sampling sites, the existing data show a good correlation between geochemistry and position in the segment. The high Mg-number samples come from the southern end of the segment, while the low Mg-number samples come from the center of the segment (Figure 6d). All of these characteristics suggest a supply of magma of relatively constant chemistry to the segment from which the erupted liquids are derived by fractionation, with the magmas erupted at the segment end being less fractionated than those at the segment center. This is the opposite of the relationship observed in the segment of the Mid-Atlantic Ridge at $24^{\circ} \mathrm{N}$ [Lawson et al., 1996], where the less fractionated lavas are found at the segment center.

\section{Discussion}

[30] A number of features of this segment allow its volcanic history to be established with some precision. These include the well-defined distinction of volcanic units on the camera images through sediment cover and stratigraphic relations, the identification of eruptive fissures in the younger units, the correlation possible between the features seen on the photographs and the side-scan imagery of the whole of the median valley floor, the well-defined relationship between faulting and volcanism, and the clear distinction between the different side-scan flow textures within the segment.

[31] In the discussion that follows, we examine the relationship between smooth-textured and hummocky-textured flows, we use the side-scan imagery and photographs to determine the history of the detailed study area, and finally we extrapolate the conclusions from that area to the segment as a whole using side scan and bathymetry.

\subsection{Nomenclature: Pillow and Sheet Flows Versus Hummocky and Smooth-Textured Flows}

[32] Traditionally submarine lava flows have been described in terms of their surface morphology as seen at the visual scale on a deep-sea camera image or through the viewport of a submersible. Lavas have been divided into pillowed flows, lobate flows and sheet flows on the basis of this surface morphology [e.g., Ballard et al., 1979; Bonatti and Harrison, 1988; Fox et al., 1987], and these morphological differences have been used to infer such parameters as eruption rate, cooling rate, and underlying slope [e.g., Bonatti and Harrison, 1988; Gregg and Fink, 1995, 2000; Griffiths and Fink, 1992]. The terms describing lava morphologies have been extrapolated from the visual scale to the textures seen on high-resolution side-scan images, so that flows that we term smooth-textured flows have been described as sheet flows [e.g., 
a)

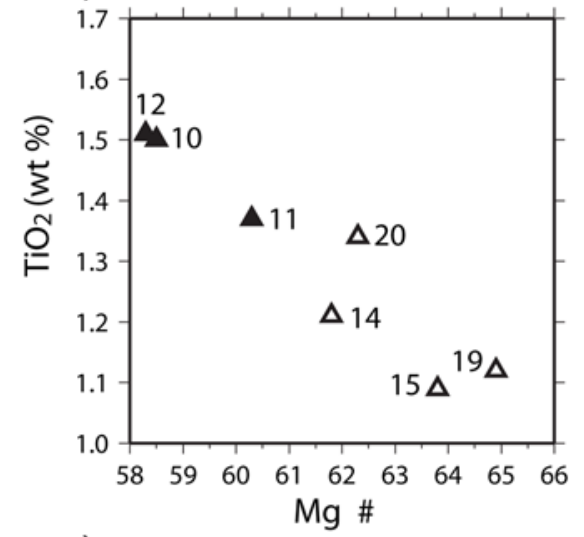

c)

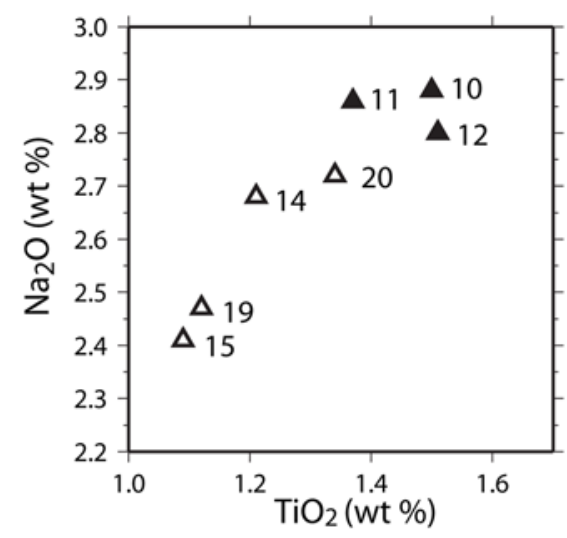

b)

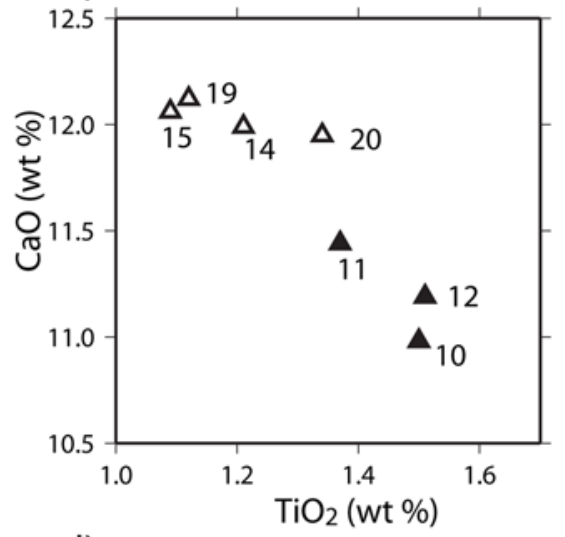

d)

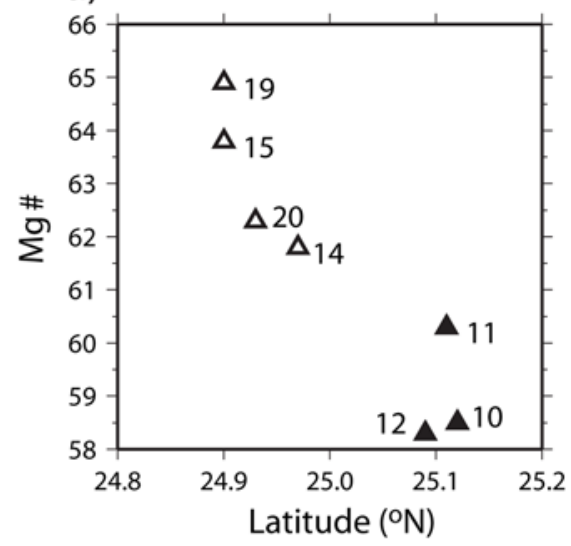

Figure 6. Electron probe analysis of glasses from seven of the dredge hauls (locations shown in Figure 1; chemical analyses given in Table 1). Samples shown with open triangles come from the southern end of the segment, while samples shown by solid triangles come from the center of the segment. (a) $\mathrm{TiO}_{2}$ versus $\mathrm{Mg}$ number shows the degree of magmatic evolution of the samples. (b and c) Examples of the variation in major element geochemistry consistent with the fractionation calculation summarized in the text. (d) Although there are few sampling sites, the existing data show a good correlation between geochemistry and position in the segment.

Parson et al., 1993; Perfit and Chadwick, 1998], while hummocky textures have been described as pillow mounds [e.g., Parson et al., 1993; Perfit and Chadwick, 1998; Smith et al., 2002a; White et al., 2002].

[33] Our observations and those of others show that while hummocky-textured flows are very commonly, perhaps almost always, capped by pillows, smooth-textured flows may be capped by any or all lava morphologies. This observation was made in the MARK area near $23^{\circ} \mathrm{N}$ at the Mid-Atlantic Ridge, where Bryan et al. [1994] showed that the flat top of Serocki Seamount has a smooth side-scan texture, but is pillowed at the seafloor. On the East Pacific Rise, an extensive survey reported by White et al. [2002] showed that though sheet flows and lobate flows are more abundant there than pil- lows, pillows are also frequently present in areas that are smooth-textured on the side-scan records, and not just where the hummocky (pillow mound) textures are seen. Similar observations were made on the Puna Ridge, the offshore extension of the Kilauea Volcano's East Rift Zone. At the Puna Ridge the smooth-textured tops of flat-topped volcanic edifices show pillows transitioning to lobates and sheets over short distances, while the side-scan texture remains smooth throughout [Smith et al., 2002a].

[34] The confusion in nomenclature extends to DSDP and ODP drill holes and ophiolites as well. In drill holes and ophiolites, the term sheet flow is used for flows with massive columnar-jointed cores, but with no reference to surface structures [Adamson, 1985; Aumento et al., 1977; Schmincke and Bednarz, 1990]. There is no necessary link 
Table 2. Summary of the Geological History of the Median Valley Floor of the $25^{\circ} \mathrm{N}$ Segment

\begin{tabular}{lll}
\hline Age, years & \multicolumn{1}{c}{$\begin{array}{c}\text { Volcanic } \\
\text { Activity }\end{array}$} & $\begin{array}{c}\text { Fault } \\
\text { Activity }\end{array}$ \\
\hline 400,000 & S3 and H3 flows start & F4 faults start \\
250,000 & last S3 and H3 lavas & F3 faults start \\
& S2 and H2 lavas start & F4 faults stop \\
120,000 & last S2 and H2 lavas & F2 faults start \\
& S1 and H1 lavas start & F3 faults stop \\
& & F4 faults \\
& & reactivated \\
25,000 & seamount in detailed & \\
& study area erupted & older F1 \\
15,000 & last S1 and H1 lavas & F2 faults start \\
& & younger F1 \\
& & faults \\
5,000 & Tadpole Ridge and & \\
4,000 & related volcanism & \\
& &
\end{tabular}

between these massive flows and those termed sheet flows from surface observations.

[35] It is clearly important to resolve this confusion. Here we attempt to use terms that are descriptive and different for each of the observation scales: smooth and hummocky for the side-scan scale, pillows, lobates and sheets for flow surfaces at the photographic scale.

\subsection{History of the Detailed Study Area}

[36] Bathymetry and side-scan imagery of the detailed study area is shown in Figure 4. From the side-scan interpretation shown in Figure 3, all of the flows in the detailed study area fall in age group 1 showing the brightest backscatter. From the photographic survey though, as was shown above, the volcanic units of the detailed study area can be assigned a relative age within group 1 on the basis of their sediment cover (see Figure 5 and Table 2). The same is possible, though with less certainty (see above) for the faults, using the thickness of the sediment cover of the talus fans at the base of fault scarps seen on photographs. The geographic distribution of the different age groups is the primary key to the geological history of the detailed study area, since it enables the creation of a relative age chronology. For example, it establishes that Tadpole ridge is younger than the smooth flows by which it is surrounded, and is not an older feature surrounded by younger flows. Similarly, the volcanic cone is clearly older than the smooth flows that surround it, but was faulted after the smooth flows were emplaced.
[37] To turn this relative chronology into ages in years depends on estimating sediment thickness, which is much more difficult and more uncertain. The sedimentation rate along this section of the Mid-Atlantic Ridge has been estimated by several authors, giving values of $4-10 \mathrm{~mm} / 1000 \mathrm{yr}$ [Lisitzin, 1972], 10-20 mm/1000 yr [Marks, 1981] and $\sim 10 \mathrm{~mm} / 1000 \mathrm{yr}$ [Emery and Uchupi, 1984]. Here we use a rate of $10 \mathrm{~mm} / 1000 \mathrm{yr}$ for our calculations, while recognizing that this figure is poorly determined. Estimating mean sediment thickness on seafloor units from photographs is not easy, since apparent sediment thickness depends on the nature of the substrate (pillows of different sizes, and talus breccia of different clast sizes) while sediment thickness varies locally across the outcrop, depending perhaps on local topography affecting the degree of sediment winnowing by deep ocean currents. Given those limitations, we estimate thicknesses on the four different lava units identified in the detailed study area as $200-300 \mathrm{~mm}$ on the lavas of the severely faulted seamount east of Tadpole ridge (Figure 5c), $100-150 \mathrm{~mm}$ on the smooth-textured S1 flows both east and west of Tadpole ridge (Figure 5b), and 30$50 \mathrm{~mm}$ on Tadpole ridge itself and other thinly sedimented units between Tadpole ridge and the faulted seamount (Figure 5a). Additional images from the camera survey of each of the three age classes are included in the auxiliary material for this paper (Figures A, B, C). On the basis of a sedimentation rate of $10 \mathrm{~mm} / 1000$ years, these sediment thicknesses correspond to ages of $20,000-30,000 \mathrm{yr}, 10,000-15,000 \mathrm{yr}$ and $3000-5000$ yr, respectively.

[38] The ages of faulting within the detailed study area can be established from the photographs in two ways. Sediment thickness on talus piles suggests two different ages for the talus in the detailed study area, an earlier age close to the age of the smooth-textured flows (10,000-15,000 yr), and a younger age close to the age of the most recent volcanism (3000-5000 yr), as explained above. The earlier faults in the camera survey can be correlated through the side-scan survey to the eastern fault zone of the pair of F1 fault zones, and can be dated as active after the eruption of the smooth flows, since smooth, horizontal flows of the same sediment cover, and hence the same inferred age, occur on each side of Tadpole ridge at depths that differ by around $75 \mathrm{~m}$. This depth difference must be due to displacement on the F1 faults. The younger faults in the camera survey do not appear to cut the younger volcanics of Tadpole 
a)

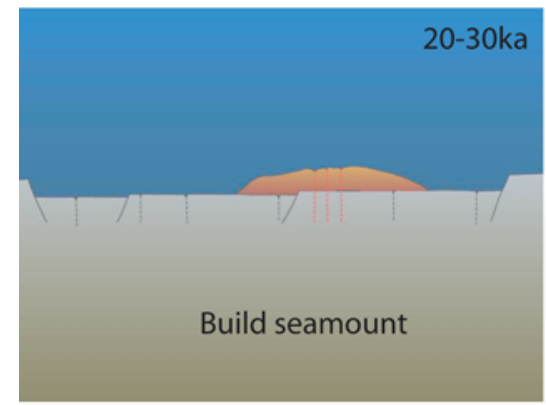

c)

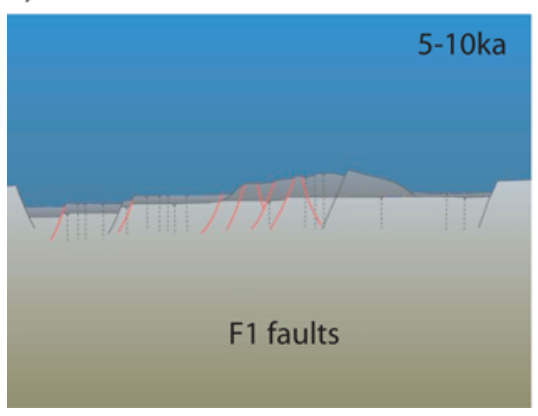

b)

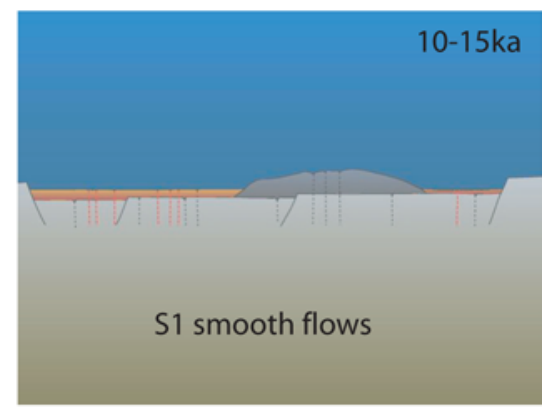

d)

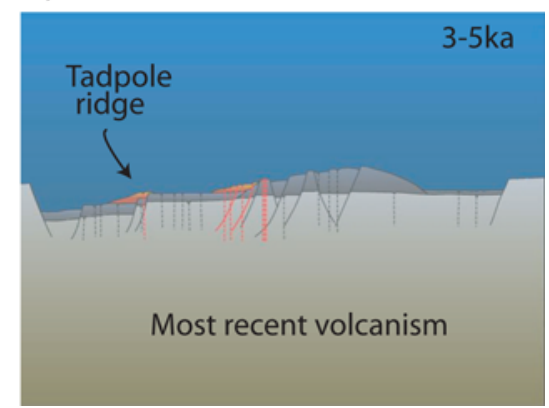

Figure 7. Four frames from a movie showing a cartoon of the evolution of the detailed survey area, interpreted from the images of the camera transect. The age span of the images is about 30,000 years. Red: recent eruption with feeding dikes, or active faults. (a) Eruption of the seamount (S1). (b) Eruption of the smooth-textured flows (S1). (c) Faulting of the seamount and smooth flows (F1 faults). (d) Eruption of the most recent flows, including Tadpole ridge $(\mathrm{H} 1)$. See Figure $3 \mathrm{~b}$ for definition of $\mathrm{S} 1, \mathrm{H} 1$, and $\mathrm{F} 1$ and Table 2 for the sequence of faulting and eruptions.

age, and are likely to predate them, but perhaps only by a short time interval. These younger faults may represent continued movement on the faults that make up the F1 fault zone.

[39] These relationships are summarized in Figure 7, which shows four frames from a movie depicting cross sections through the detailed study area at different stages in its history. Each cross section, and hence each frame in the movie, was based on the details of the discussion above. When shown in sequence they illustrate the evolution of the detailed study area over the last 20,000$30,000 \mathrm{yr}$. The entire movie is available in the auxiliary material, from which it can be downloaded and viewed.

\subsection{Extrapolation to the Wider Survey Area}

\subsubsection{Duration of Smooth Flow Eruptions}

[40] The smooth-textured flows can be assigned relative ages throughout the survey area using observations of backscatter amplitude on the TOBI side-scan map [Mitchell, 1993]. The S1 and H1 flows that have the brightest backscatter, and are inferred to be the youngest flows erupted, are confined within the pair of F2 fault zones within the median valley floor (see Figure 3). The F2 fault zones are separated by 3-4 km, between which there are also a few occurrences of older smoothtextured (S2) flows. The two F2 fault zones thus probably limited the length of lava flows erupted up until a few thousand years ago, and acted to pond lavas during that period. The earlier phase of eruption of smooth flows (S2) is similarly limited by the pair of F3 fault zones that lie farther out, and an even older phase of smooth flows (S3) runs up to the major F4 faults that mark the edge of the median valley floor. This relative chronology of events within the segment is well established by the relative backscatter amplitude on the side-scan image.

[41] As in the detailed study area, it is not easy to turn these relative ages into dates in years. In these older units, there is no direct observation of sediment thickness, and dates have to be derived by means of stratigraphic relationships. These dates are necessarily uncertain and are based on assumptions about the fault activity in the median valley floor. However, the clarity with which the geological relationships are seen in the smooth flow area 
at the center of the segment does allow more precise conclusions than in other segments of the Mid-Atlantic Ridge. The dating of these earlier phases of volcanism relies on the relation between the lava units of different ages and the faulting. Since the lava units of a particular age class are usually bounded by one of the fault zones, the time of initiation of each fault zone must postdate the eruption of the latest lavas that lie on the seafloor farther from the spreading axis than that fault zone. Once a fault zone has started to move, later lava flows are confined by it.

[42] Within the detailed study area, the pair of F1 fault zones that cuts the S1 smooth flows are spaced about $1 \mathrm{~km}$ apart on either side of the spreading axis, and date from somewhat later than about 10,000-15,000 years ago, as argued above. These faults must have been initiated at about this position, since there has only been time for them to spread apart by $200-400 \mathrm{~m}$. Since both faults of the pair are very close to the center of the median valley, both can be assumed to be active simultaneously. To take this discussion further, we assume that the older pairs of fault zones farther out on the median valley floor were initiated simultaneously, at about the same distance apart within the median valley floor as the F1 faults are today. Given that assumption their age of initiation can be calculated from the spreading rate of $25 \mathrm{~mm} / \mathrm{yr}$. On that basis the F2 faults that are about $4 \mathrm{~km}$ apart and bound the central panel of smooth-textured S1 lavas would have initiated about 120,000 years ago, and presumably became inactive a few thousand years ago when the F1 fault zones were initiated after the last smooth $\mathrm{S} 1$ flows were erupted. The youngest S2 lavas in the panel outside the central panel would then have the same age as the initiation of the F2 faults on their inner side, of about 120,000 years old, and would be expected to be covered by about $1-1.5$ meters of sediment.

[43] Extending this argument further, the F3 fault zones which lie about $3.5 \mathrm{~km}$ from the spreading axis, would have formed about 250,000 years ago. Then the youngest smooth flows of the S3 unit, bounded on the inner side by the 250,000 year fault zone, and on the outside by the F4 median valley wall faults, would have the same age, and would be expected to be covered by about 2.5 meters of sediment. The median valley wall faults would then have been initiated about 400,000 years ago.

[44] These arguments lead to the conclusion that smooth-textured flows have been erupting in the central section of this segment for at least a quarter of a million years. Whatever are the conditions that lead to the eruption of smooth-textured flows, these must have continued for that length of time, rather than being a short-lived phenomenon, as we supposed in our previous paper [Smith et al., 1995]. However, almost all of the most recent volcanism at the $25^{\circ} \mathrm{N}$ segment is hummocky-textured, though there is a small patch of smooth-textured flows within the hummocky flows. Perhaps the long-lived series of eruptions that gave rise to the smooth-textured flows over the last quarter of a million years is coming to an end. Perhaps the recent eruptions are the start of the construction of an axial volcanic ridge within a segment that has not had one for a very long time.

\subsubsection{Nature of the Fault Zones}

[45] The same stratigraphic relationships that allow the dating of the lava units also carry information about the evolution of the fault zones. The youngest of the pairs of fault zones, F1, cuts the S1 lava flows in the segment center, but is covered by the Tadpole Ridge and the youngest hummocky volcanics south of it, if the fault zones extend as far south as that. The F1 faults are clearly synvolcanic faults since, as they evolve, the depression created will be largely or wholly filled in by lava flows. In the north, where it appears that no volcanism has occurred since the faults were initiated, the faults have throws of 100-150 m, but the eastern fault scarp has been entirely covered by the Tadpole Ridge. Even if the faults continue moving, eventually the height of the fault scarps exposed at the seafloor will be much less than the throw on the faults.

[46] The F2 fault zones lie at the limit of the S1 volcanics. During the evolution of these fault zones, the S1 lava flows did not overflow the fault scarps, but were ponded against them, filling in some or all of the space created by the fault movement. The present scarp height on the F2 faults is variable. In places it reaches $100 \mathrm{~m}$, but in others is only a few tens of meters. Since the faults were active during the volcanism, the throw on the F2 faults must increase with depth in the lava pile, reaching perhaps several hundreds of meters at the base of the lavas. It is not clear from the stratigraphy of the area whether the F2 fault zones are still active or not.

[47] The F3 fault zones are clearly currently much less active, if they are active at all. These fault zones limit the S2 lavas, which again must have ponded against the faults while they were active. 
Yet the fault scarp heights are small, so very little fault movement can have occurred since the last lavas were erupted, and the youngest S2 lavas are estimated to have erupted about 120,000 years ago (see above). By contrast the F4 fault zones, the current boundary faults of the median valley floor, have clearly recently been active, and have scarp heights of $100-500 \mathrm{~m}$.

[48] All of these observations suggest that the fault zones in the median valley are active in two stages, first after they have been initiated close to the center of the median valley until a new pair of faults has been initiated inside them, and again after they have spread 3-4 kilometers away from the center of the valley. In between there is an interval within which they become inactive for a period of time. In turn this suggests that there are two separate mechanisms involved in generating the faults in this segment of the Mid-Atlantic Ridge, one that produces faults in association with the volcanic eruptions close to the segment center and the other that reactivates and amplifies the early faults to create the median valley wall faults.

[49] This conclusion, if it can be applied more widely than in this segment, adds an extra element to the scenario proposed by [McAllister and Cann, 1996] for the evolution of boundary wall faults. The observations here indicate strongly a two-stage growth in faults rather than the single phase of faulting proposed in that paper.

\subsubsection{Recent Deformation of the Median Valley Floor}

[50] The youngest (S1) smooth flows in the center of the segment have been cut and deformed by the pair of F1 fault zones that border a central depression about $150 \mathrm{~m}$ deep within the center of the median valley floor (Figures 2 and 4). It is possible to estimate the size of this depression with some accuracy because the plains are gently sloping inward on either side of the fault zones that are defined by the smooth flows. The side-scan image (Figure 3) shows that the fault zones are each made up of many separate fault strands, in places more than ten, each with a small throw. Major faults may initiate as such zones, in which some of the strands are amplified at the expense of others until one major fault results [e.g., Cowie, 1998; Escartín et al., 1999; McAllister et al., 1995].

[51] The depression may mark a pause in magma supply after the extrusion of the last smooth flows at about 10,000-15,000 years ago. If so, then it would be possible to model it as crust thinned by necking, giving rise both to a depression at the seafloor, and a corresponding elevation of the Moho beneath. Because the density contrast between basalt and seawater is about 5 times that between lower crust and mantle, the total crosssectional area of missing crust would, on this very simple model, be 6 times the cross sectional area of the depression at the seafloor. The cross-sectional area at the seafloor is about $0.25 \mathrm{~km}^{2}$, so that the total cross sectional area of missing crust would be about $1.5 \mathrm{~km}^{2}$. At a spreading rate of $25 \mathrm{~mm} / \mathrm{yr}$ and for a crustal thickness of $6 \mathrm{~km}$, this deficit represents a time period of about 10,000 years since the eruption of the last smooth-textured flows, which is consistent with the calculations of 10,000-15,000 years based on sedimentation rate. This geological history is summarized in Table 2.

\subsubsection{Recent Eruptions in the $25^{\circ} \mathrm{N}$ Segment}

[52] Our photographic survey allows the possibility of estimating the recurrence intervals between volcanic eruptions at this segment. As discussed in detail above, the most recent eruption is that of Tadpole ridge (3000-5000 years ago). Before that is the last eruption of the smooth-textured S1 flows that surround the faulted seamount $(10,000-$ 15,000 years ago). Before that again is the formation of the faulted seamount $(20,000-30,000$ years ago). Between the formation of the faulted seamount and the eruption of the last of the smooth flows there may have been earlier smooth flows in the interval of 10,000 to 15,000 years between the two events. But along the camera track there is no evidence for any eruption between the last of the smooth flows and the eruption of Tadpole ridge (see Figure 7 and the movie in the auxiliary material).

[53] Tadpole ridge itself, and the units of the same age a few hundred meters to the east of Tadpole ridge, are relatively small, with a total crosssectional area of about $10^{4} \mathrm{~m}^{2}$. The side-scan imagery shows, however, that Tadpole ridge is only the northern tip of a much larger area of recent volcanism (Figure 3). One of these units, centered at $25^{\circ} 04^{\prime} \mathrm{N}, 45^{\circ} 28^{\prime} \mathrm{W}$ is the volcanic ridge of which Tadpole ridge is the most northern part (Figures 2 and 3). Overall it is $9 \mathrm{~km}$ long and $2 \mathrm{~km}$ wide, elongate along the spreading axis. It has been erupted over the eastern F1 fault zone, and at its thickest is about $100 \mathrm{~m}$ thick. Its volume is about $0.33 \mathrm{~km}^{3}$. Another unit lies somewhat farther to the 
south. It is in two parts, a volcanic ridge $3 \mathrm{~km}$ long by $2 \mathrm{~km}$ wide, up to $120 \mathrm{~m}$ thick, with a volume of $0.18 \mathrm{~km}^{3}$, and a large flat-topped seamount at $24^{\circ} 58.5^{\prime} \mathrm{N}, 45^{\circ} 27.5^{\prime} \mathrm{W}$, which is $2 \mathrm{~km}$ in diameter at its base, $240 \mathrm{~m}$ high and has a volume of $0.33 \mathrm{~km}^{3}$. Somewhat to the east of these units is a small patch of smooth flows apparently of very small volume. Together the total volume of these very young flows is $0.84 \mathrm{~km}^{3}$. If these have been erupted over the last 5000 years, this corresponds to a mean eruption rate of $1.7 \times 10^{5} \mathrm{~m}^{3} / \mathrm{yr}$.

[54] If this volume rate of eruption represents the steady state supply, for the $25 \mathrm{~km}$ length of the spreading axis imaged by our side-scan survey, given a total spreading rate of $25 \mathrm{~mm} / \mathrm{yr}$, such a volume rate of eruption would yield a lava layer for the whole segment about $300 \mathrm{~m}$ thick. This thickness of the volcanic layer is consistent with seismic estimates of the thickness of Layer $2 \mathrm{a}$ at the MidAtlantic Ridge [e.g., Hussenoeder et al., 2002], and the thickness of extrusives in DSDP Hole 395A [Aumento et al., 1977]. This suggests that the mean eruption rate that has generated the most recent lavas is not too far from the overall steady state for the segment.

[55] All of the calculations of the previous three sections could only be made because of the presence of the large area carpeted by smoothtextured flows in this segment. Not only can the relative backscatter intensity be much better estimated for smooth flows, but the horizontal surface defined by the flows can be used as a datum for calculations of deformation. Neither approach can be used for the regions covered by the more common hummocky flows of the northern Mid-Atlantic Ridge.

\subsubsection{Erupting Smooth and Hummocky- Textured Flows}

[56] The boundary between the hummocky and smooth flows has fluctuated with time (see Figure $3 \mathrm{~b}$ for reference). At the time of the oldest S3 and H3 flows, the boundary was at about $25^{\circ} 05^{\prime} \mathrm{N}$, close to its position at the present-day, while during the eruption of the $\mathrm{S} 2$ and $\mathrm{H} 2$ flows of intermediate age the boundary between the two flow types is located about 10 kilometers farther south (note contact on west side of the valley floor). The boundary at any one time is relatively sharp. There are several outliers of one type of volcanism within another, but the transition is rapid close to the major boundary between the smooth and hummocky flows.
[57] The lava morphology does not seem to be related to lava geochemistry. Though the lava at the segment ends is less evolved than that at the segment center, the samples from the segment center come both from the smooth-textured S1 flows (dredge hauls 10 and 11) and from the younger hummocky-textured Tadpole ridge (dredge 12).

[58] The contrast between smooth and hummockytextured flows represents a major difference in the style of volcanic eruption. Though the origin of that difference cannot be deduced from our survey alone, comparison with styles of basaltic eruption on land, and with cross sections of submarine flows in the Troodos ophiolite, suggest a possible model.

[59] The symmetrical shape of individual hummocks in the hummocky-textured side-scan imagery suggests that each hummock is fed through a central, probably vertical, narrow tube from which narrower tubes branch, eventually feeding the flow front. Each hummock is one flow lobe of a larger lava flow composed of many hummocks. In such a flow, lava would be fed from an eruptive vent to the flow through a major tube, which branches and feeds several hummocks that grow simultaneously. At some point, when a hummock is a few tens of meters tall, the back pressure within the feeder tube will cause a rupture, and a new hummock will be initiated. Visual observation of hummocks in this study and others uniformly report that they are composed of pillows, which is why they have been given the name "pillow mounds" by other authors [e.g., Chadwick and Embley, 1994; Perfit and Chadwick, 1998; Sinton et al., 2002; White et al., 2002]. In the Troodos ophiolite, eruptive units are seen in cross section that are several meters or more thick and are made entirely of pillows [Schmincke and Bednarz, 1990]. These may be the same features as the hummocks of the ocean floor.

[60] Smooth-textured flows on side-scan images are mapped by multibeam bathymetry as relatively flat, with very uniform low-angle surface slopes. At the visual scale, submarine smooth-textured flows may show a variety of surface morphologies, including pillows (e.g., as seen in this study, at the Puna Ridge [Smith et al., 2002a], and at Serocki volcano [Bryan et al., 1994]), and sheet and lobate forms (e.g., as seen at the East Pacific Rise [White et al., 2002] and Puna Ridge [Smith et al., 2002a]).

[61] At the visual scale, the surfaces of many subaerial pahoehoe lava flows, as seen in Hawaii, 
show a similar variety of surface flow structures to the visual scale of the submarine observations, including sheet textures and lobate units. On land, pahoehoe flows are fed through tubes or channels that widen into a sheet of lava in the center of each flow lobe. As the flow continues, the flow lobes may inflate by injection of lava to become several meters or even tens of meters thick [Hon et al., 1994]. In cross section, pahoehoe flows contain a core of massive lava [e.g., Self et al., 1997, 1998]. We envision the submarine smooth-textured flows forming in a similar way to the inflated pahoehoe lavas on land. Flows with similar massive, columnar-jointed cores are also seen in cross section in the Troodos ophiolite [Schmincke and Bednarz, 1990], and probably are sections through smooth-textured flows. An important point is that the lava morphology on the surfaces of these massive-cored flows may vary greatly, even from place to place on a single flow, and thus may not be a good indicator of the characteristics of the flow.

[62] The segment centered on $25^{\circ} \mathrm{N}$ is the only one between the Kane Fracture Zone at $23^{\circ} \mathrm{N}$ and the Atlantis Fracture Zone at $30^{\circ} \mathrm{N}$ to have the particular combination of properties that accompanies the extensive smooth-textured flows: a wide and gently sloping median valley floor, and absence of an axial volcanic ridge. In a search of the available bathymetric surveys of the 45 segments of the MidAtlantic Ridge between $15^{\circ} \mathrm{N}$ and $35^{\circ} \mathrm{N}$ [Thibaud et al., 1998] we identified six other segments with apparently similar characteristics. These are the segments centered at $15^{\circ} 30^{\prime} \mathrm{N}, 18^{\circ} 15^{\prime} \mathrm{N}, 18^{\circ} 45^{\prime} \mathrm{N}$, $19^{\circ} 30^{\prime} \mathrm{N}, 22^{\circ} 55^{\prime} \mathrm{N}$ and $33^{\circ} 25^{\prime} \mathrm{N}$. Only a detailed side-scan survey can test whether these segments show the same smooth/hummocky combination seen at $25^{\circ} \mathrm{N}$, but it is interesting that all seven segments share other properties as well. In particular they have shallower than normal depths to the floor of the median valley at the segment center and have relatively small numbers of small earthquakes detected by hydrophone recording [Smith et al., 2002b]. Both of those properties are consistent with the segments being magmatically active [Smith et al., 2002b].

[63] There is an apparent relationship between the style of volcanism as imaged by side-scan sonar and spreading rate. Along the axis of the East Pacific Rise, smooth-textured flows are much more abundant than hummocky flows [e.g., Crane, 1987; Fornari et al., 1985; White et al., 2002], while the reverse is true at the Mid-Atlantic Ridge [e.g., Briais et al., 2000; Lawson et al.,
1996; Smith et al., 1995]. At the slow-spreading (20 mm/yr) Reykjanes Ridge, where the gross topographic morphology mimics that of fast spreading ridges, apparently because of the influence of the Iceland hot spot, side-scan images show that the volcanic morphology is predominantly hummocky [e.g., Magde and Smith, 1995; Parson et al., 1993].

[64] On a global scale, what is the reason for fast spreading ridges axes having predominantly more smooth-textured flows and slow-spreading ridges hummocky-textured flows? In general, magmas erupted at mid-ocean ridges are of very similar chemistry all around the world, and thus of very similar physical properties at the same temperature (e.g., see global and regional averages from PetDB database at Lamont-Doherty Earth Observatory [Lehnert et al., 2000]). This means that the usual explanation for changing flow type, increase or decrease in viscosity, is unlikely to be the reason. A difference in physical properties might arise if in places magma becomes partly crystalline before or during eruption. In our dredged samples we do see differences in phenocryst content between lavas collected within regions of uniform side-scan texture, so differences in crystallinity are unlikely to be the cause of the difference in lava type either. This leaves eruption rate as a likely candidate for causing the difference between the two flow textures, with slower eruption rates leading to development of branching networks of tubes, and faster eruption rates to flows with a core of molten lava, as has been suggested by others [e.g., Perfit and Chadwick, 1998].

[65] Within a single segment, as in the $25^{\circ} \mathrm{N}$ segment, both smooth and hummocky-textured flows may be found together, suggesting that the same magmatic system may produce one type of product or another depending on the location within the segment. At any one time in the $25^{\circ} \mathrm{N}$ segment, hummocky flows are more common toward the southern end of the segment, while smooth flows are more common near the segment center. If eruption rate is a control on flow morphology, then the smooth flows at the segment center may be the result of more rapid lava effusion than the hummocky flows at the southern end and the change in the position of the hummocky/ smooth boundary through time may reflect changes in the vigor of the magmatic system as a whole. Varying magmatic vigor along the length of a segment and through time may be important features of other segments too, where the volcanology 
may not reveal the changing eruptive conditions as clearly as here.

\section{Acknowledgments}

[66] This project was funded by an NERC grant that enabled Charles Darwin cruise 65 and by NSF grant OCE-9811575. We thank Eric Condliffe for chemical analyses of basalt glasses on the University of Leeds electron probe. We thank Dan Fornari for his assistance with the WHOI Towcam and D. Bohnenstiehl, M. Fowler, P. Gregg, and S. Corey for helping with camera maintenance and data collection during cruise Atlantis 4-4. We also thank the captain and crew of the $\mathrm{R} / \mathrm{V}$ Atlantis for their support and hard work during the camera deployment and retrieval. The authors had many fruitful discussions with H. Schouten, D. Fornari, and A. Soule. We also thank the reviewers of this paper, W. Chadwick and N. Mitchell, for their helpful and insightful advice.

\section{References}

Adamson, A. C. (1985), Basement stratigraphy, Deep Sea Drilling Project Hole 504B, Initial Rep. Deep Sea Drill. Proj., $83,121-127$.

Aumento, F., et al. (1977), Initial Reports of the Deep Sea Drilling Project, vol. 37, 1008 pp., U.S. Govt. Print. Off., Washington, D. C.

Ballard, R. D., R. T. Holcomb, and T. H. van Andel (1979), The Galapagos rift at $86^{\circ} \mathrm{W}: 2$. Sheet flows, collapse pits, and lava lakes of the rift valley, J. Geophys. Res., 84(B10), 5407-5422.

Blackman, D. K., J. R. Cann, B. Janssen, and D. K. Smith (1998), Origin of extensional core complexes: Evidence from the Mid-Atlantic Ridge at Atlantis Fracture Zone, J. Geophys. Res., 103, 21,315-21,333.

Bonatti, E., and C. G. A. Harrison (1988), Eruption styles of basalt in oceanic spreading ridges and seamounts: Effect magma temperature and viscosity, J. Geophys. Res., 93, 2967-2980.

Briais, A., H. Sloan, L. M. Parson, and B. J. Murton (2000), Accretionary processes in the axial valley of the Mid-Atlantic Ridge $27^{\circ} \mathrm{N}-30^{\circ} \mathrm{N}$ from TOBI side-scan sonar images, Mar. Geophys. Res., 21, 87-119.

Bryan, W. B., S. E. Humphris, B. Thompson, and J. Casey (1994), Comparative volcanology of small axial eruptive centers in the MARK area, J. Geophys. Res., 99, 29732984.

Chadwick, W. W., and R. W. Embley (1994), Lava flows from a mid-1980s submarine eruption on the Cleft Segment, Juan de Fuca Ridge, J. Geophys. Res., 99, 4761-4776.

Cowie, P. A. (1998), Normal fault growth in three-dimensions in continental and oceanic crust, in Faulting and Magmatism at Mid-Ocean Ridges, Geophys. Monogr. Ser, vol. 106, edited by W. R. Buck et al., pp. 325-348, AGU, Washington, D. C.

Crane, K. (1987), Structural evolution of the East Pacific Rise axis from $13^{\circ} 10^{\prime} \mathrm{N}$ to $10^{\circ} 35^{\prime} \mathrm{N}$ : Interpretations from SeaMARC I data, Tectonophysics, 136, 65-124.

Emery, K. O., and E. Uchupi (1984), The Geology of the Atlantic Ocean, 1050 pp., Springer, New York.

Escartín, J., P. A. Cowie, R. C. Searle, S. Allerton, N. C. Mitchell, C. J. MacLeod, and A. P. Slootweg (1999), Quantifying tectonic strain and magmatic accretion at a slow- spreading ridge segment, Mid-Atlantic Ridge, $29^{\circ} \mathrm{N}, \mathrm{J}$. Geophys. Res., 104, 10,421-10,437.

Fornari, D. J. (2003), A new deep-sea towed digital camera and multi-rock coring system, Eos Trans. AGU, 84(8), 6971.

Fornari, D. J., W. B. F. Ryan, and P. J. Fox (1985), Sea-floor lava fields on the East Pacific rise, Geology, 13, 413-416.

Fox, C. G., K. M. Murphy, and R. W. Embley (1987), Automated display and statistical analysis of interpreted deep-sea bottom photographs, Mar. Geol., 78, 199-216.

Gregg, T. K. P., and J. H. Fink (1995), Quantification of submarine lava-flow morphology through analog experiments, Geology, 23(1), 73-76.

Gregg, T. K. P., and J. H. Fink (2000), A laboratory investigation into the effects of slope on lava flow morphology, J. Volcanol. Geotherm. Res., 96, 145-159.

Gregg, T. K. P., and D. K. Smith (2003), Volcanic investigations of the Puna Ridge, Hawaii: Relations of lava flow morphologies and underlying slopes, J. Volcanol. Geotherm. Res., 126, 63-77.

Griffiths, R. W., and J. H. Fink (1992), Solidification and morphology of submarine lavas: A dependence on extrusion rate, J. Geophys. Res., 97, 19,729-19,737.

Hon, K., J. Kauahikaua, R. Denlinger, and K. Mackay (1994), Emplacement and inflation of pahoehoe sheet flows: Observations and measurements of active lava flows on Kilauea Volcano, Hawaii, Geol. Soc. Am. Bull., 106, $351-$ 370.

Hussenoeder, S. A., G. M. Kent, and R. S. Detrick (2002), Upper crustal seismic structure of the slow spreading MidAtlantic Ridge, $35^{\circ} \mathrm{N}$ : Constraints on volcanic emplacement processes, J. Geophys. Res., 107(B8), 2156, doi:10.1029/ 2001JB001691.

Lawson, K., R. C. Searle, J. A. Pearce, P. Browning, and P. Kempton (1996), Detailed volcanic geology of the MARNOK area, Mid-Atlantic Ridge north of Kane transform, in Tectonic, Magmatic, Hydrothermal and Biological Segmentation of Mid-Ocean Ridges, edited by C. J. MacLeod, P. A. Tyler, and C. L. Walker, Geol. Soc. Spec. Publ., 118, 61-102.

Lehnert, K., Y. Su, C. H. Langmuir, and U. Nohl (2000), A global geochemical database structure for rocks, Geochem. Geophys. Geosyst., 1(5), doi:10.1029/1999GC000026.

Lisitzin, A. P. (1972), Sedimentation in the World Ocean, With Emphasis on the Nature, Distribution, and Behavior of Marine Suspensions, 218 pp., Spec. Publ. SEPM Soc. Sediment. Geol., vol. 17, Soc. of Econ. Paleontol. and Mineral., Tulsa, Okla.

Magde, L., and D. K. Smith (1995), Seamount volcanism at the Reykjanes Ridge: Relationship to the Iceland hotspot, J. Geophys. Res., 100, 8449-8468.

Marks, S. N. (1981), Sedimentation on new ocean crust: The Mid-Atlantic Ridge at 37N, Mar. Geol., 43, 65-82.

McAllister, E., and J. R. Cann (1996), Initiation and evolution of boundary wall faults along the Mid-Atlantic Ridge, 25$29^{\circ} \mathrm{N}$, in Tectonic, Magmatic, Hydrothermal and Biological Segmentation of Mid-Ocean Ridges, edited by C. J. MacLeod, P. A. Tyler, and C. L. Walker, Geol. Soc. Spec. Publ., 118, 29-48.

McAllister, E., J. Cann, and S. Spencer (1995), The evolution of crustal deformation in an oceanic extensional environment, J. Struct. Geol., 17(2), 183-199.

Mitchell, N. C. (1993), A model for attenuation of backscatter due to sediment accumulations and its application to determine sediment thicknesses with GLORIA sidescan sonar, J. Geophys. Res., 98, 22,477-22,493. 
Parson, L. M., et al. (1993), En echelon axial volcanic ridges at the Reykjanes Ridge: A life cycle of volcanism and tectonics, Earth Planet. Sci. Lett., 117, 73-97.

Perfit, M. R., and W. W. Chadwick (1998), Magamtism at mid-ocean ridges: Constraints from volcanological and geochemical investigations, in Faulting and Magmatism at Mid-Ocean Ridges, vol. 106, edited by W. R. Buck et al., pp. 59-116, AGU, Washington, D. C.

Purdy, G. M., J. C. Sempere, H. Schouten, D. L. Dubois, and R. Goldsmith (1990), Bathymetry of the Mid-Atlantic Ridge, $24^{\circ}-31^{\circ} \mathrm{N}$ : A map series, Mar. Geophys. Res., 12, 247-252.

Schmincke, H.-U., and U. Bednarz (1990), Pillow, sheet flows and breccia flow volcanoes and volcano-tectonic hydrothermal cycles in the extrusive series of the northeastern Troodos ophiolite, in Ophiolites: Oceanic Crustal Analogues, edited by J. Malpas et al., pp. 207-216, Geol. Surv. Dept., Nicosia, Cyprus.

Self, S., T. Thordarson, and L. Keszthelyi (1997), Emplacement of continental flood basalt lava flows, in Large Igneous Provinces, Geophys. Monogr. Ser., vol. 100, pp. 381-410, Washington, D. C.

Self, S., L. Keszthelyi, and T. Thordarson (1998), The importance of pahoehoe, Annu. Rev. Earth Planet. Sci., 26, 81110.

Sempéré, J. C., J. Lin, H. S. Brown, H. Schouten, and G. M. Purdy (1993), Segmentation and morphotectonic variations along a slow-spreading center: The Mid-Atlantic Ridge $\left(24^{\circ} \mathrm{N}-30^{\circ} 40^{\prime} \mathrm{N}\right)$, Mar. Geophys. Res., 15, 153-200.

Sinton, J., E. Bergmanis, K. Rubin, R. Batiza, T. K. P. Gregg, K. Grönvold, K. C. Macdonald, and S. M. White (2002), Volcanic eruptions on mid-ocean ridges: New evidence from the superfast spreading East Pacific Rise, $17^{\circ}-19^{\circ} \mathrm{S}, \mathrm{J}$. Geophys. Res., 107(B6), 2115, doi:10.1029/2000JB000090.

Smith, D. K., and J. R. Cann (1992), The role of seamount volcanism in crustal construction at the Mid-Atlantic Ridge $\left(24^{\circ} \mathrm{N}-30^{\circ} \mathrm{N}\right)$, J. Geophys. Res., 97, 1645-1658.

Smith, D. K., and J. R. Cann (1993), Building the crust at the Mid-Atlantic Ridge, Nature, 365, 707-715.
Smith, D. K., et al. (1995), Mid-Atlantic ridge volcanism from deep-towed side-scan sonar images, $25^{\circ}-29^{\circ} \mathrm{N}, \mathrm{J}$. Volcanol. Geotherm. Res., 67, 233-262.

Smith, D. K., L. S. Kong, K. T. M. Johnson, J. Reynolds, and the Cruise Participants of TN084 (2002a), Volcanic structure of the Puna Ridge, Kilauea Volcano, in Evolution of Hawaiian Volcanoes: Recent Progress in Deep Underwater Research, Geophys. Monogr. Ser, vol. 128, edited by E. Takahashi et al., pp. 125-142, Washington, D. C.

Smith, D. K., M. Tolstoy, C. G. Fox, D. R. Bohnenstiehl, H. Matsumoto, and M. J. Fowler (2002b), Hydroacoustic monitoring of seismicity at the slow-spreading Mid-Atlantic Ridge, Geophys. Res. Lett., 29(11), 1518, doi:10.1029/ 2001 GL013912.

Smith, D. K., J. Escartin, M. Cannat, M. Tolstoy, C. G. Fox, D. R. Bohnenstiehl, and S. Bazin (2003), Spatial and temporal distribution of seismicity along the northern Mid-Atlantic Ridge $\left(15^{\circ}-35^{\circ} \mathrm{N}\right)$, J. Geophys. Res., 108(B3), 2167, doi:10.1029/2002JB001964.

Spencer, S., D. K. Smith, J. R. Cann, J. Lin, and E. McAllister (1997), Structure and stability of non-transform discontinuities on the Mid-Atlantic Ridge between $24^{\circ} \mathrm{N}$ and $30^{\circ} \mathrm{N}$, Mar. Geophys. Res., 19, 339-362.

Thibaud, R., P. Gente, and M. Maia (1998), A systematic analysis of the Mid-Atlantic Ridge morphology and gravity between $15^{\circ} \mathrm{N}$ and $40^{\circ} \mathrm{N}$ : Constraints of the thermal structure, J. Geophys. Res., 103, 24,223-24,243.

Tucholke, B. E., J. Lin, M. C. Kleinrock, M. A. Tivey, T. B. Reed, J. Goff, and G. E. Jaroslow (1997), Segmentation and crustal structure of the western Mid-Atlantic Ridge flank, $25^{\circ} 25^{\prime}-27^{\circ} 10^{\prime} \mathrm{N}$ and $0-29$ m.y., J. Geophys. Res., 102, $10,203-10,223$.

White, S. M., R. M. Haymon, D. J. Fornari, M. R. Perfit, and K. C. Macdonald (2002), Correlation between volcanic and tectonic segmentation of fast-spreading ridges: Evidence from volcanic structures and lava flow morphology on the East Pacific Rise at $9^{\circ}-10^{\circ} \mathrm{N}$, J. Geophys. Res., 107(B8), 2173, doi:10.1029/2001JB000571. 